\title{
Collateral and Yield Spread of Syndicated Loans
}

\author{
Khaled Amira ${ }^{1} \&$ Mark L. Muzere ${ }^{2}$ \\ ${ }^{1}$ St. Bonaventure University, USA \\ ${ }^{2}$ Langston University, USA \\ Corresponding author: Khaled Amira, St. Bonaventure University, St. Bonaventure NY 14778, USA
}

Received: May 23, 2018

Accepted: June 23, 2018

Online Published: June 27, 2018

doi:10.5430/afr.v7n3p180

URL: https://doi.org/10.5430/afr.v7n3p180

\section{JEL classification: G21}

\begin{abstract}
We examine factors that influence the use of collateral in syndicated loans and explore debt contract theories under adverse selection and moral hazard. Using a probit model (Agresti, 2007) to analyse syndicated loan data (1987-2007) for firms in the United States, we find that loan and borrower specific factors and general economic conditions as well are significant in explaining the presence of collateral in these loans. Further testing exploring the relationship between collateral and yield spread of syndicated loans while using an econometric procedure (Heckman, 1976; Lee, 1978) to control for the simultaneity between the decision to use collateral and the determination of the yield spread confirms the empirical predictions of the moral hazard debt theory. The use of collateral reduces risk and the cost of borrowing for syndicated loans, providing further clarification to the mixed empirical evidence in the literature.
\end{abstract}

Keywords: information asymmetry

\section{Introduction}

Collateral, a major feature of debt contracts, is a topic that continues to draw attention in the literature. (Note 1) Research suggests that the presence of collateral in debt contracts mitigates the effects of the asymmetry of information between borrowers and lenders. Collateral may solve the adverse selection problem where borrowers have private information unknown to lenders, before they grant the loans, which may lead to credit rationing due to the inability of lenders to price the loans according to the borrowers' qualities (Stiglitz \& Weiss, 1981). In this case, high quality borrowers use collateral as a signal to convey valuable information to lenders to lower borrowing costs. For low quality borrowers, this signal is expensive as the high probability of default may lead to the loss of collateral. This argument provides support for the idea that collateral is negatively related to credit risk (see, for example, Bester, 1985; Chan \& Kanatas, 1985; Besanko \& Thakor, 1987). Other research explains the use of collateral through the nature of lender-borrower relationships. The relationships between lenders and borrowers mitigate information asymmetry and the associated agency costs, therefore reducing the need for collateral once these relationships are built (Boot \& Thakor, 1994).

Collateral may also solve the moral hazard problem where the risk characteristics of borrowers are known to lenders but their actions after getting the loans are not. As such, it acts as a disciplinary measure on borrowers. Collateral protects lenders from the consequences of borrowers' ex post decisions, for example, those decisions related to underinvestment and asset substitution (Jensen \& Meckling, 1976; Myers, 1977; Stulz \& Johnson, 1985). Low quality borrowers, therefore, pledge collateral to support their loans. This argument suggests a positive relationship between collateral and credit risk. (Note 2) Others, however, argue that lender-borrower relationships can evolve into a monopoly position (hold-up situation) by lenders where old borrowers will be asked to pledge collateral to get additional loans, thus, leading to a positive relationship between collateral and relationship between lender and borrower (Rajan, 2002; Sharpe, 1990; Greenbaum, Kanatas, \& Venezia, 1989).

Although many aspects of syndicated loans have been studied (see, for example, Sufi, 2007; Dennis \& Mullineaux, 2000), there is little empirical investigation of the use of collateral in syndicated loans. Because these loans are provided by a group of lenders (a syndicate) to a single borrower under the direction of one or several lenders serving as lead managers, syndicated loans represent a cross between traditional commercial lending and underwriting of debt. The market for syndicated loans has been growing at a fast rate and has become a dominant way for issuers of debt to tap these funds from banks and other institutional capital providers. (Note 3) In this 
research, we attempt to fill this gap. We examine how factors like maturity, loan size, covenants, borrower firm size, credit rating, borrowing experience, syndicate size, real GDP growth and real interest rate affect the decision to use collateral in syndicated loans. Further, we explore the empirical predictions of debt contract theories under adverse selection and moral hazard on the use of collateral in syndicated loans.

We use a probit model (Agresti, 2007) to examine syndicated loan data (1987-2007) for firms in the United States (US). We find that the likelihood of the use of collateral in syndicated loans increases with longer loan maturities, lower number of lenders in a syndicate, smaller loan sizes, lower credit rating, lower sales, higher frequency of borrowing, larger number of facilities comprising the load deal, when there are dividend restrictions, when there are no financial covenants, lower GDP growth, when the borrower is a private firm, when it is a term loan, and when the loan is used for recapitalization, take over and LBO purposes.

We use an econometric procedure (Heckman, 1976; Lee, 1978) to control for the interdependence between the decision to use collateral and the decision to fix the yield spread. This econometric technique first takes parameters from the probit model to construct the inverse Mills ratio, which is then used as an independent variable in an OLS regression to explain the spread. Two sets of estimates are derived, one for the sample consisting only of loans with collateral and the other for the sample consisting of loans without collateral. The two regressions give opposite results on the role of collateral. One estimate suggests that pledging collateral reduces the spread, while the other suggests that doing so raises the spread. To try to find sensible results, we apply the parameters estimated from the sample with collateral to the sample without collateral and vice versa. We find that the borrowers who initially pledged collateral and switched to unsecured loans will still pay higher spread than the one paid by unsecured borrowers. Also, borrowers who initially borrowed on unsecured basis will still pay less than those who borrowed on secured basis. Overall, these results show that borrowers would be better off borrowing on unsecured basis, confirming the predictions of the moral hazard theory that low-quality borrowers pledge collateral to reduce the cost of borrowing, whereas high quality borrowers issue unsecured loans.

We contribute to the large literature on the use of collateral in debt contracts. (Note 4) The previous literature deals with the use of collateral in standard debt contracts, our research is concerned with syndicated loans, however. Our contribution is in many important ways, all are based on many categories of factors and on the largest data of syndicated loans available in the US market. First, we include a larger number of categories of syndicated loan types and purposes and company types as determinants of collateral. Second, we explore the effects of financial and dividend restriction covenants as determining factors. Previous studies considered only the joint effects of these factors, but these covenants have different purposes. The financial covenants enforce minimum financial performance measures against a borrower and are strong because the borrower must maintain regular compliance or suffer a technical default on the loan agreement. Dividend covenants, on the other hand, restrict the ability of the borrower to distribute cash to the shareholders. Third, we also explore the effect of economic conditions in the US on the use of collateral in syndicated loans. Thus, this research provides further clarifications to the mixed empirical evidence in the literature and adds new evidence on the factors that influence the use of collateral in loan contracts.

\section{Determinants of the Use of Collateral}

\subsection{Loan-Specific Factors}

Maturity. Long-term loans would hold collateral as they require continuous and long-term evaluation by lenders. Creditworthiness of the borrowers may change overtime. Adverse events have higher chance of occurrence for long-term loans. Therefore, pledging collateral may reduce the impact of this risk. The pledging of collateral allows the lender to ensure a certain value in the future. Over the long run, collateral is most likely to preserve value while the company may not (Mann, 1997).

The presence of collateral also reduces the asset-substitution problem that may arise when long-term debt is granted (Jackson \& Kronman, 1979). Once long-term debt is granted, borrowers may switch to higher risk projects. If the debt is short term, it would be costly for the firm to switch to higher risk projects. Therefore, short term debt will not need collateral (Leeth \& Scott, 1989). In most of the empirical research, the finding is that there a positive effect of maturity on the likelihood of the presence of collateral (Leeth and Scott, 1989; Boot, Thakor, and Udell, 1991; Harhoff and Korting, 1998; Degryze and Van Cayselee, 2000; and Voordeckers \& Steijvers, 2006). We expect to find a positive relationship between loan maturity and the likelihood of the use of collateral. The alternative hypothesis is the absence of such relationship.

Loan Size. According to Jackson and Kronman (1979), larger loans are more frequently secured because the advantages of the collateral (reduced asset substitution, claim dilutions, reduced foreclosure costs) overcome the 
fixed cost of monitoring, assets appraisal and other administrative expenses associated with loans. According to Leeth and Scott (1989), and Avery, Bostic, and Samolyk (1998), loan size is related to probability of default; larger loans increase the leverage of the borrowers hence the risk of non-repayment. Therefore, large loans increase the need for collateral. Alternatively, loan size can be an indicator of credit risk. There tends to be more rigorous screening of large-scale loans, resulting in a lower level of credit risk and less likelihood of the use of collateral.

The empirical findings about loan size are mixed. Harhoff and Korting (1998), Elsas and Krhanen (1998), Degreyse and Van Cayseele (2000) and Jimenez, Salas, \& Saurina (2006) find that large size loans are often secured. Berger and Udell (1990), and Boot, Thakor, and Udell (1991), and Booth and Booth (2006) find that large loans are less secured. We expect a negative relationship between the loan size and the likelihood of collateral. The alternative hypothesis predicts a positive such relationship.

Loan covenants. A covenant is a promise by a borrower to refrain from taking certain types of actions that would hurt the interests of the lender while the loan is outstanding. Covenants generally fall into three categories: affirmative covenants, negative covenants, and financial covenants. Lenders try to mitigate agency and adverse selection problems associated with risky debt by including covenants in their debt contracts. Smith and Warner (1979) suggest that one way to mitigate conflicts between shareholders and bondholders and reduce agency costs is by constraining the behaviour of managers via covenants to align their interests with those of bondholders. According to Smith and Warner, the cost imposed on firms by covenant restrictions is offset by the benefit of reducing agency costs, hence reducing the cost of debt. Covenants and collateral are proxies for the risk of a debt issue. Therefore, we expect that depending on the types of covenants they may increase or decrease the likelihood of the use of collateral. The alternative hypothesis predicts the opposite result.

Financial covenants impose minimum financial performance measures on the borrower. Failure to maintain this minimum puts the borrower in default and the principal becomes due. Penalties may be imposed, or loan terms may be renegotiated. These covenants are so strong that their presence decreases the likelihood of collateral. For negative covenants, the borrower's activities are constrained in some way. For example, dividend covenants restrict the ability of the firm to distribute cash to the shareholders. These restrictions may affect the maximum amount, frequency or recipient of the dividends. As these restrictions limit future cash disbursements, they may complement the use of collateral. Therefore, we expect a direct relationship between dividend restrictions and the likelihood of the use of collateral. In the alternative hypothesis, we do not expect such direct relationship.

Loan purpose. Lenders may require collateral on certain loan purposes. We include dummy variables for loan purposes. We consider the eight major categories in terms of the number of facilities and we group the rest under other loan purposes. The loan purpose categories are: debt repayment, corporate purposes, working capital, takeover, LBO/MBO, acquisition line, recapitalization and commercial paper (CP) back up. We expect loans raised for Acquisition, LBOs and Takeover to be associated with the presence of collateral. These loans are for highly leveraged transactions, so they carry more risk which requires more monitoring. Booth (1992) shows that these loans have an additional cost, according to the loss of monitoring information spill overs associated with public equity. Loans used for debt repayment and recapitalization are expected to be secured. Loans used for corporate purposes, working capital and CP back up are less likely to be secured mainly because they are not highly speculative. We expect the opposite effect in the alternative hypothesis.

Loan type. Lenders may require collateral on certain loan types. We include dummy variables for loan types. We consider the six major categories in terms of number of facilities and we group the remaining under other loan types. The loan type categories are: 364-day facility, bridge loans, delay draw term, revolver/line, revolver/term loan, term loan.

A revolver/line or revolving credit line allows borrowers to draw down, repay, and re-borrow. Under these facilities borrowers are charged an annual commitment fee on unused amounts, which increases the total borrowing cost. This type of facility gives more flexibility to borrowers but increases risk to lenders as the commitment of borrowers continuously changes. The revolvers expose lenders to quantity risk (Ho \& Saunders, 1983). Therefore, we expect that revolvers increase the likelihood of the use of collateral. In the alternative hypothesis, we expect a decrease in the likelihood of the use of collateral.

364-days are an example of a revolving line of credit and are generally limited to the investment-grade market. Regulatory capital guidelines mandate that, after one year of extending credit under a revolving facility, banks must then increase their capital reserves to cover the unused amounts. Therefore, banks can offer issuers 364-day facilities at a lower unused fee than a multiyear revolving line of credit. We expect that raising these types of facilities reduces the likelihood of the use of collateral. We expect an increase in the use of collateral in the alternative hypothesis. 
Term loans are another type of syndicated loans. They are instalment loans. They can be amortised term loans, with progressive repayment schedules, or institutional term loans (term loan B, C, and D) destined for non-bank institutional investors. As these loans are drawn under short term commitment periods and they must repaid, we expect these loans to increase the likelihood of the use of collateral. We predict a decrease of the likelihood of collateral use in the alternative hypothesis.

Bridge loans are loans that are intended to provide short-term financing to provide a "bridge" to an asset sale, bond offering, stock offering, divestiture, etc. Generally, bridge loans are provided by arrangers as part of an overall financing package. Also, bridge loans are a form of interim financing that tend to be assessed as highly risky. They are supposed to be replaced by more stable financing that may or may not materialise due to economic conditions. Typically, the issuer will agree to increase interest rates if the loan is not repaid as expected. Because of the short-term nature of these loans and the assets that back them, we expect a decrease in the likelihood of the use of collateral. The opposite effect is predicted in the alternative hypothesis.

\subsection{Borrower-Specific Factors}

Firm size. Firm size is a proxy for information asymmetry (Diamond \& Verrechia, 1991; Harris, 1994). Larger firms also have lower probability of financial distress, thus resulting in a lower default risk premium (Mansi, Maxwell, \& Miller, 2006). Therefore, due to the lower degree of credit risk with larger firms, we expect the likelihood of the use of collateral to decrease as well. An increase in the likelihood of the use of collateral is expected in the alternative hypothesis.

Credit rating. Credit ratings on corporate bonds and municipal bonds might contain additional information on default not available in the standard indicators of default risk (Ederington, Yawitz, and Roberts, 1987; and Moon and Stotsky, 1993). In assessing the loss-given defaults of loans, credit rating agencies look at a variety of factors among them the amount of collateral pledged, the amount of other debt subordinated to the loan, the degree of control over the collateral security that the lender exercises and covenant constraints.

Credit rating is taken as the average of Moody's and S\&P bond ratings at the time of issue. Jewel and Levingston (1998) suggest that using this definition of credit rating provides the most efficient measure of default risk premium. Credit ratings are computed using a conversion process where $A A A$ rated loans are assigned a value of 22 and $D$ rated bonds receive a value of 1 . For example, a company rated as $A l$ by Moody's and $A+$ by S\&P would receive an average score of 18. In Appendix, we provide the conversion scheme for both Moody's and S\&P credit ratings used in this study. Credit rating as an indicator of the credit quality of a borrower quality lowers the information asymmetry about the borrower (Dennis \& Mullineaux, 2000; Gonas, Highfield, \& Mullineaux, 2004; Lee \& Mullineaux, 2004). Therefore, we expect a lower likelihood of collateral use with higher the credit rating. We expect the opposite effect in the alternative hypothesis.

Frequency or repeated experience of borrowing. Ozler (1992) examines the effect of borrowing frequency in the Eurocurrency market by focusing on sovereign loans between 1968 and 1981. Ozler provided two empirical measures of borrowing frequency of borrowing: the cumulative number of loans given to a borrower and the cumulative number of months in which the borrower receives a loan. She finds that repeated experience affects the evolution of spread. Specifically, spreads start at high values at low levels of experience or frequency of borrowing and decrease as experience increases.

None of the previous studies have explicitly examined each borrower after initially entering the syndicated loan market and then borrowing repeatedly thereafter. The frequency of borrowing affects the likelihood of borrowing. If a longer experience in the syndicated loan market contributes to trust and transparency, then the frequency of borrowing will be negatively related to the likelihood of the use of collateral. On the other hand, if a longer experience means more accurate information is known about the borrower's debt capacity, then the experience increases the likelihood of the use of collateral. We expect the frequency of borrowing or repeated experience to be positively related to the likelihood of the use of collateral. We expect the opposite effect in the alternative hypothesis.

Following Ozler (1992), we use two measures of repeated experience or frequency of borrowing: the cumulative number of prior months in which a company gets a syndicated loan and the cumulative number of loans issued by a firm.

\subsection{Macroeconomic and Other Factors}

The number of lenders. Prior research has emphasised the importance of this characteristic in the pricing of syndicated loans. The number of lenders in a syndicated loan is strongly related to the quality of information about a 
borrower and the probability of the borrower's default. Lee and Mullineaux (2004) find that loan syndicates are smaller when there is less information about the borrower, and the borrower's credit risk is high, and the loan is secured. Sufi (2007) finds that fewer lenders join a loan syndicate when the borrower is opaque. That is, the borrower needs more monitoring and due diligence. He also argues that arrangers add more members to the syndicate when a borrower is likely to renegotiate the loan, thus when he is likely to default. Given that unanimity is needed to change major terms of the loans adding more participants makes renegotiation more difficult and prevents strategic default by the borrowers. Therefore, a higher number of lenders acts as a deterrent to strategic default will lower the likelihood of the use of collateral. We expect the opposite effect in the alternative hypothesis.

Macroeconomic variables. The macroeconomic environment and economic conditions affect the decision to pledge collateral. Lenders ask for collateral during declining economic conditions. Jimenez et al. (2006) explore Spanish loans between 1984 and 2002. They find that a higher output growth lowers the likelihood of the use of collateral. They also find that the likelihood of the use of collateral decreases if monetary policy is tight or real interest rates are high. We use GDP growth rate and real interest rates to represent macroeconomic conditions. We expect economy upturn to be negatively related to the likelihood of the use collateral. In the alternative hypothesis, we expect a positive such relationship.

Other control variables. The number of tranches may also affect the likelihood of collateral. A syndicated loan with more than one tranche needs more monitoring by the lenders therefore this increases the likelihood of the use of collateral. We expect a decrease in the likelihood of collateral use in the alternative hypothesis. To reduce the biasness of the results we control for the fixed effects of the geography and the industry of a borrower. The region of the borrower may affect the likelihood of the use of collateral. Depending on the laws, economic conditions and other characteristics prevalent in a state may affect the likelihood of the use of collateral. We represent this effect by a dummy variable for each of the 50 states in the United States.

The industry of the borrower may also affect the likelihood of the use of collateral. The nature of the business may differ from one borrower to another. Project risk and availability of collateral may differ from one industry to another. Certain industries are more capital intensive which require the use of collateral. We use the first two digits of the sic code to classify an industry. Industry is a factor because sectors naturally go in and out of favour. For this reason, having a loan in a desirable sector like telecom in the late 1990s or healthcare in the early 2000s can help loan syndication. Also, defensive loans (like consumer products) can be more appealing during times of economic uncertainty, whereas cyclical borrowers (like chemicals or autos) can be more appealing during economic booms.

\section{Data and Variable Measures}

We obtain the data on syndicated loans from the Loan Pricing Corporation's Dealscan which contains detailed information on syndicated loans, contract terms, and lenders. The data collected consist of syndicated loans issued by US corporations in dollars covering the period from January 1987 to January 2007. The database has an unbalanced panel structure with varying observations over time for different borrowers. After eliminating data without information on the security clauses, we are left with 31,250 facilities involving 9,503 lenders. We obtain macro-economic data from the Federal Reserve of Saint Louis.

We classify the variables in our analysis into three main categories: loan-specific measures, borrower-specific measures, and macroeconomic variables. We also include month and year of issue, industry of the issuer, and region of the issuer proxied by the state. Loan specific measures include the yield spread, size, maturity, number of members in the lending syndicate, and year of issue. Borrower specific measures include credit rating, repeated experience of borrowing, and borrower size proxied by sales. Table 1 contains a summary of the definitions of the variables and how they are denoted in the analysis. Additional definitions of the variables are provided below. 
Table 1. Definitions of variable measures

\begin{tabular}{|c|c|c|}
\hline Variable & Symbol & Definition/Measured \\
\hline Secured & $\mathrm{Sec}$ & A binary variable equal to if the loan is secured and zero otherwise \\
\hline Yield Spread & YSpread & $\begin{array}{l}\text { All-in Spread drawn is the amount a borrower pays in basis points over } \\
\text { LIBOR for each dollar drawn down. It includes the spread on the loan } \\
\text { and other fees paid to the syndicate members }\end{array}$ \\
\hline Log of the Issue Size & Size & Natural log of the issue size \\
\hline Term to Maturity & Term & Number of months until maturity \\
\hline Credit Ratings & Rating & $\begin{array}{l}\text { Credit ratings are measured using S\&P ratings based on a numerical } \\
\text { conversion process in which AAA+ rated bonds are assigned a value of } \\
23 \text { and D rated bonds are assigned a value of } 1 .\end{array}$ \\
\hline Number of tranches & Ntranches & The number of facilities in a syndicated loan deal \\
\hline Private & Priv & $\begin{array}{l}\text { A dummy variable equal } 1 \text { if the borrower is a private firm and zero } \\
\text { otherwise }\end{array}$ \\
\hline Dividend covenants & Divcov & $\begin{array}{l}\text { A dummy variable equal } 1 \text { if there are dividend restrictions and zero } \\
\text { otherwise }\end{array}$ \\
\hline Financial Covenants & Fincov & $\begin{array}{l}\text { A dummy variable equal } 1 \text { if there are financial covenants and zero } \\
\text { otherwise }\end{array}$ \\
\hline $\begin{array}{l}\text { Repeated Experience } \\
\text { of Borrowing }\end{array}$ & Exp & $\begin{array}{l}\text { Experience or frequency of borrowing measured as the cumulative } \\
\text { number of loans issued by a borrower or the cumulative number } \\
\text { months in which the borrower issued a bond. }\end{array}$ \\
\hline Sales & Sales & Log of the book value of sales of the borrower \\
\hline Number of lenders & Nlenders & The total number of lenders participating the syndicated loan \\
\hline GDP Growtht-1 & Econ & Growth of the real GDP in the previous year the loan is made \\
\hline Loan type & Ltype & Dummy variable for the (7) loan types \\
\hline Loan purpose & Lpurpose & Dummy variable for the (9) loan purposes \\
\hline State of the borrower & State & Dummy variable for the $(50)$ states of the borrower \\
\hline Industry of the borrower & Ind & $\begin{array}{l}\text { Dummy variable for the (10) industrial division based on the two-digit } \\
\text { SIC code. }\end{array}$ \\
\hline Time of issue & Time & $\begin{array}{l}\text { The time of issue is the month in which the loan is made. It is } \\
\text { measured using a dummy variable that takes the value of } 1 \text { when the } \\
\text { loan is made in a certain month and zero otherwise. }\end{array}$ \\
\hline
\end{tabular}

Table 2 presents sample characteristics for the variables used in the sample. In the analysis, we evaluate syndicated loan facilities. There may be more than one tranche or facility in a syndicated loan deal. In our sample, $64 \%$ of these loan deals contain only one tranche. The rest of the loan deals contain between 2 and 10 tranches. There are 31,250 facilities for 20,528 syndicated loan deals. Even though a syndicated loan contract is structured at the deal level, pricing, maturity, loan type, loan purpose and therefore risk attributes may vary with the facility which justifies our analysis at the tranche level. The results presented in this paper are robust under the deal level analysis. In the analysis below, we focus on the statistics for facilities referred to as loans. 
Table 2. Sample Characteristics

Panel A. Loans and borrowers' characteristics

\begin{tabular}{|c|c|c|c|c|}
\hline & Overall & Secured & Unsecured & $\%$ secured \\
\hline Number of Loans & 31,150 & 24,684 & 6,668 & $78.73 \%$ \\
\hline \multicolumn{5}{|l|}{ Loan Types } \\
\hline 364-Day Facility & 2049 & 611 & 1438 & $29.82 \%$ \\
\hline Bridge Loan & 500 & 349 & 151 & $69.80 \%$ \\
\hline Delay Draw Term & 367 & 332 & 35 & $90.46 \%$ \\
\hline Revolver/Line of credit & 16946 & 12831 & 4115 & $75.72 \%$ \\
\hline Revolver/Term Loan & 679 & 536 & 143 & $78.94 \%$ \\
\hline Term Loan & 10335 & 9633 & 702 & $93.21 \%$ \\
\hline Other Loan Types & 474 & 390 & 84 & $82.28 \%$ \\
\hline \multicolumn{5}{|l|}{ Loan purpose } \\
\hline Acquisition line & 1973 & 1709 & 264 & $86.62 \%$ \\
\hline CP backup & 1077 & 140 & 937 & $12.99 \%$ \\
\hline Corporate Purposes & 6113 & 4360 & 1753 & $71.32 \%$ \\
\hline Debt Repay. & 7045 & 5634 & 1411 & $79.97 \%$ \\
\hline $\mathrm{LBO} / \mathrm{MBO}$ & 2372 & 2271 & 101 & $95.74 \%$ \\
\hline Recapitalisation & 1285 & 1216 & 69 & $94.63 \%$ \\
\hline Takeover & 4319 & 3679 & 640 & $85.18 \%$ \\
\hline Working Capital & 4991 & 3854 & 1137 & $77.22 \%$ \\
\hline Other Loan Purposes & 2175 & 1819 & 356 & $83.63 \%$ \\
\hline \multicolumn{5}{|l|}{ Borrower Type } \\
\hline Public & 20819 & 15412 & 5407 & $74.03 \%$ \\
\hline Rated & 9691 & 6327 & 3364 & $65.29 \%$ \\
\hline Unrated & 11128 & 9085 & 2043 & $81.64 \%$ \\
\hline Private & 7226 & 6365 & 861 & $88.08 \%$ \\
\hline
\end{tabular}

Note: This table provides loans and borrowers characteristics for the sample. Included are loan type, loan purpose, and borrower type. The data set is comprised of 31,350 syndicated loan facilities made between January1987 and January 2007. Variable descriptions are provided in Table 1. 
Panel B. Descriptive Statistics of Syndicated Loans

\begin{tabular}{|c|c|c|c|c|c|c|}
\hline & $\mathbf{N}$ & Mean & Median & $\begin{array}{l}\text { Standard } \\
\text { Deviation }\end{array}$ & Minimum & Maximum \\
\hline \multicolumn{7}{|l|}{ Syndicated Loans } \\
\hline Spread & 29,490 & 229.131 & 225.000 & 138.6403 & -4.000 & 1450.000 \\
\hline Term & 30,353 & 50.432 & 58.000 & 26.8309 & 0.000 & 421.000 \\
\hline Size (Millions) & 31,349 & 229.408 & 87.000 & 561.344 & 0.053 & 25000.000 \\
\hline Rating & 14,002 & 10.392 & 10.000 & 3.7407 & 1.000 & 22.000 \\
\hline Number of managers & 466 & 1.165 & 1.000 & 0.7128 & 1.000 & 6.000 \\
\hline Sales (Millions) & 28,309 & 2589.134 & 501.300 & 12539.475 & 0.215 & $5.489 \mathrm{E}+5$ \\
\hline Number of lenders & 31,297 & 8.960 & 5.000 & 11.5350 & 1.000 & 290.000 \\
\hline Number of tranches & 31,350 & 1.989 & 2.000 & 1.1136 & 1.000 & 10.000 \\
\hline \multicolumn{7}{|l|}{ Without Collateral } \\
\hline Spread & 6,306 & 99.577 & 75.000 & 87.9104 & 5.500 & 1000.000 \\
\hline Term & 6,435 & 39.936 & 36.000 & 23.8554 & 0.000 & 360.000 \\
\hline Size (Millions) & 6,667 & 508.718 & 240.000 & 975.700 & 0.500 & 25000.000 \\
\hline Rating & 3,977 & 13.369 & 14.000 & 3.3745 & 1.000 & 22.000 \\
\hline Number of managers & 199 & 1.111 & 1.000 & 0.5842 & 1.000 & 6.000 \\
\hline Sales (Millions) & 6,261 & 6772.572 & 1768.423 & 2416.5467 & 1.000 & $5.489 \mathrm{E}+5$ \\
\hline Number of lenders & 6,661 & 11.843 & 9.000 & 10.6714 & 1.000 & 119.000 \\
\hline Number of tranches & 6,668 & 1.448 & 1.000 & 0.7418 & 1.000 & 8.000 \\
\hline \multicolumn{7}{|l|}{ With Collateral } \\
\hline Spread & 23,184 & 264.369 & 250.000 & 128.6095 & -4.000 & 1450.000 \\
\hline Term & 23,918 & 53.255 & 60.000 & 26.8866 & 0.000 & 421.000 \\
\hline Size (Millions) & 24,682 & 153.962 & 65.000 & 341.088 & $5,3814.69$ & $13,600.000$ \\
\hline Rating & 10,025 & 9.211 & 9.000 & 3.1809 & 1.000 & 22.000 \\
\hline Number of managers & 267 & 1.206 & 1.000 & 0.7939 & 1.000 & 6.000 \\
\hline Sales (Millions) & 22,048 & 1401.157 & 387.000 & 5449.638 & 0.215 & $3.36099 \mathrm{E}+5$ \\
\hline Number of lenders & 24,636 & 8.182 & 4.000 & 11.6358 & 1.000 & 290.000 \\
\hline Number of tranches & 24,682 & 2.135 & 2.000 & 1.1515 & 1.000 & 10.000 \\
\hline
\end{tabular}

Note: This table provides summary statistics regarding the data employed in our analysis. The data set comprises of 31,350 syndicated loan facilities made between January1987 and January 2007. Descriptive statistics include: loan yield spread (Spread) in basis points, term to maturity (Term) in number of months, the loan size (Size) in US dollars, S\&P credit rating, number of managers syndicating the loan, sales amount of the borrowing firm in US dollars, number of lenders participating in the syndicate, number of tranches or facilities comprising the loan deal. 
Panel A of table 2 presents the descriptive statistics regarding the types and purposes of the loans, and the types of the borrowers. There are 17 major loan types in the data sample. We report the 6 major categories in terms of the number of loan issues and group the rest under other loan types. Only 29\% of the 2,049 364-day facilities are secured. These are short term credits which are generally limited to the investment grade market, thus there is a lower need for security. About $70 \%$ of the 500 bridge loans are secured. These loans are intended to provide short term financing as "bridge" to asset sales or bond offerings, stock offerings, anticipation to longer term financing. They are offered as part of an overall financing package which increases the possibility of default. Thus, they are frequently secured. About $90 \%$ of the 367 delay draw term loans are secured and $93 \%$ of the 10,335 term loans are secured. These are instalment loans that are drawn on or after the closing date in one or more instalments. Amounts repaid may not be re-borrowed. These loans may have longer maturity and they may be carved for institutional investors as part of a leveraged credit. They are typically associated with high default risk. About $76 \%$ of the 16,946 revolvers/lines of credit are secured. These revolving lines of credit act like a corporate credit card and they are most of time collateralized. About $93 \%$ of the revolvers/term loans are secured. These are unfunded commitments that the borrower may drawdown, repay and re-borrow. The continuous nature of the commitments of explains the high frequency of security.

There are 30 different loan purpose categories in the data sample. We report the first 8 categories in terms of the number of issues and we group the rest under other loan purposes. Around 93\% of the total loans are used for purposes such as debt repayment, corporate purposes, working capital, takeover, LBO/MBO, acquisition line or recapitalization and commercial papers (CP) back up. Only 13\% of the loans used for $\mathrm{CP}$ back up are secured and $95 \%$ of loans used for LBO/MBO and recapitalization are secured. More than $70 \%$ of the loans used for the rest of the categories are secured. This high occurrence of collateral in these categories reflects the increase in leverage and default risk. The presence of collateral is associated with the default risk of the loan.

There are 9,503 different companies from 49 different states that tap the syndicated loan market. Of the 31,250 loans, $24,684(78.73 \%)$ are secured, $11,128(35.50 \%)$ are granted to unrated public companies, 9,691 (31.00\%) to rated public companies, 7,227 (23\%) to private companies and the remaining $10 \%$ have missing information on the type of borrower. Of the 24,684 secured loans, $26 \%$ are granted to unrated public firms, $26 \%$, to rated public firms, and $26 \%$ to private firms.

Panel B of Table 2 presents descriptive statistics for the variables used in the sample, which includes 31,350 facilities. Included are mean, median, standard deviation, maximum and minimum values for the variables in the analysis. Syndicated loans are issued with an average spread of 229 basis points over LIBOR, a standard deviation of 128.64 basis points, a maximum of 1,250 basis points, and a minimum of -4 basis points. This wide range of spread shows that syndicated loans are granted across all the distribution on risk. The mean size of a syndicated loan is \$229.4 million with a maximum size of $\$ 25$ billion, which was raised by AT\&T Corporation at the end of year 2000 . Syndicated loans are granted for a term of as long as 421 months and as short as a few days. The mean maturity is 50.4 months. The average credit rating of the syndicated loan borrower is 10 (BB-), with the highest grade reaching 22 (AAA) and the lowest grade assigned 1 (D), and many borrowers are not rated. On average 9 lenders participate in a syndicated loan with a minimum of 1 lender and a maximum of 290 lenders. On average one manger leads the deal but there can be as many as 6 lead managers. On average a syndicated loan deal has around 2 tranches or facilities, with a maximum of 10 tranches and a minimum of 1 tranche. Borrowers that tap the syndicated loan market have an average sales figure of \$ 2.5 billion with a minimum of \$ 214 thousand and a maximum of \$549 billion.

Secured syndicated loans are issued on average with longer maturity, higher spread, smaller amount, lower credit rating, smaller number of lenders, more tranches per deal, and by smaller borrowers than the non-secured loans. All the means for the variables are statistically significantly different from zero based on the T-tests, and the means of the secured and unsecured sample are statistically different from each other at the 1 percent level.

The average maturity is 53.25 months for secured loans and 40 months for unsecured loans. The mean loan spreads over LIBOR are 229.43 basis points and 186.24 basis points for secured and unsecured loans respectively. The average facility size is about $\$ 154$ million for secured loans and $\$ 509$ million for unsecured loans. A borrower of secured loans has a B+ credit rating while a borrower of non-secured loan has an average of BBB-. On average 8 lenders participate in a secured syndicated loan while this number is 11 for non-secured loans. Secured loans have on average 2.13 tranches per loan deal while non-secured loans have 1.44 tranches per loan deal. A borrower of secured loan has on average $\$ 1.4$ billion of sales while the non-secured loan borrower has an average of $\$ 6.8$ billion of sales. 


\section{Empirical Results}

\subsection{Determinants of Collateral}

We use a probit model (Agresti, 2007) to evaluate the impact of the various factors on the decision to use collateral in a syndicated loan. We formulate the model on the pledge of collateral in a syndicated loan as

$$
\begin{aligned}
\operatorname{Pr}_{\left(\text {Secured }_{i j}=1\right)=\Phi} & \alpha_{0}+\alpha_{1} \text { Size }_{i}+\alpha_{2} \text { Term }_{i}+\alpha_{3} \text { Rating }_{i} \\
& +\alpha_{4} \text { Tranches }_{i}+\alpha_{5} \text { Priv }_{i}+\alpha_{6} \text { Div Cov }_{i} \\
& +\alpha_{7} \text { FinCov }_{i}+\alpha_{8} \text { Exp }_{i}+\alpha_{9} \text { Sales }_{i}+\alpha_{10} \text { Lenders }_{i} \\
& \left.+\alpha_{11} \text { Econ }_{i}+\alpha_{12} \text { LType }_{i}+\alpha_{13} \text { LPurpose }_{i}+\tau+\imath+\eta\right)
\end{aligned}
$$

Where $i$ and $j$ denote the loan and the borrower respectively, $\Phi($.$) is the standard normal cumulative distribution$ function, Secured is a dummy variable that takes on a value of 1 if the loan has a collateral, $\tau$ represents industry fixed effect, $\iota$ represents time fixed effect, and $\eta$ represents state or region effect.

Table 3 provides the results from our primary specifications and reports the marginal effects of each independent variable on the change in the probability of pledging collateral, that is, the change in the probability for an

\begin{tabular}{|c|c|c|c|c|c|c|c|c|}
\hline & \multicolumn{2}{|c|}{ Specification 1} & \multicolumn{2}{|c|}{ Specification 2} & \multicolumn{2}{|c|}{ Specification 3} & \multicolumn{2}{|c|}{ Specification 4} \\
\hline & Coeffici-ent & $\begin{array}{c}\text { Marginal } \\
\text { effect }\end{array}$ & Coefficie-nt & $\begin{array}{c}\text { Marginal } \\
\text { effect }\end{array}$ & Coefficient & $\begin{array}{c}\text { Marginal } \\
\text { effect }\end{array}$ & Coefficient & $\begin{array}{c}\text { Marginal } \\
\text { effect }\end{array}$ \\
\hline \multicolumn{9}{|l|}{ Loan } \\
\hline \multicolumn{9}{|l|}{ Characteristics } \\
\hline \multirow[t]{2}{*}{ Credit Rating } & & & & & $-0.139^{\mathrm{a}}$ & $-0.039^{\mathrm{a}}$ & $-0.153^{\mathrm{a}}$ & $-0.043^{\mathrm{a}}$ \\
\hline & & & & & $(0.011)$ & $(0.003)$ & $(0.011)$ & $(0.003)$ \\
\hline \multirow[t]{2}{*}{ Sales } & & & $-0.214^{\mathrm{a}}$ & $-0.050^{\mathrm{a}}$ & $-0.183^{\mathrm{a}}$ & $-0.052^{\mathrm{a}}$ & & \\
\hline & & & $(0.017)$ & $(0.004)$ & $(0.024)$ & $(0.007)$ & & \\
\hline \multirow[t]{2}{*}{ Number of lenders } & $-0.164^{\mathrm{a}}$ & $-0.038^{\mathrm{a}}$ & $-0.125^{\mathrm{a}}$ & $-0.029^{\mathrm{a}}$ & $-0.127^{\mathrm{a}}$ & $-0.036^{\mathrm{a}}$ & $-0.141^{\mathrm{a}}$ & $-0.040^{\mathrm{a}}$ \\
\hline & $(0.0203)$ & $(0.005)$ & $(0.021)$ & $(0.005)$ & $(0.033)$ & $(0.009)$ & $(0.032)$ & $(0.009)$ \\
\hline \multirow[t]{2}{*}{ Term } & $0.004^{\mathrm{a}}$ & $0.001^{\mathrm{a}}$ & $0.003^{\mathrm{b}}$ & $0.001^{\mathrm{b}}$ & $0.006^{\mathrm{a}}$ & $0.002^{\mathrm{a}}$ & $0.007^{\mathrm{a}}$ & $0.002^{\mathrm{a}}$ \\
\hline & $(0.001)$ & $(0.000)$ & $(0.001)$ & $(0.000)$ & $(0.001)$ & $(0.000)$ & $(0.001)$ & $(0.000)$ \\
\hline \multirow[t]{2}{*}{ Size } & $-0.300^{\mathrm{a}}$ & $-0.069^{\mathrm{a}}$ & $-0.160^{\mathrm{a}}$ & $-0.037^{\mathrm{a}}$ & $-0.175^{\mathrm{a}}$ & $-0.050^{\mathrm{a}}$ & $-0.274^{\mathrm{a}}$ & $-0.077^{\mathrm{a}}$ \\
\hline & $(0.019)$ & $(0.004)$ & $(0.022)$ & $(0.005)$ & $(0.034)$ & $(0.009)$ & $(0.032)$ & $(0.008)$ \\
\hline \multirow{2}{*}{$\begin{array}{l}\text { Frequency of } \\
\text { borrowing }\end{array}$} & $0.046^{\mathrm{a}}$ & $0.011^{\mathrm{a}}$ & $0.058^{\mathrm{a}}$ & $0.013^{\mathrm{a}}$ & $0.047^{\mathrm{a}}$ & $0.013^{\mathrm{a}}$ & $0.041^{\mathrm{a}}$ & $0.012^{\mathrm{a}}$ \\
\hline & $(0.007)$ & $(0.001)$ & $(0.007)$ & $(0.001)$ & $(0.009)$ & $(0.002)$ & $(0.009)$ & $(0.002)$ \\
\hline \multirow[t]{2}{*}{ Number of tranches } & $0.295^{\mathrm{a}}$ & $0.068^{\mathrm{a}}$ & $0.325^{\mathrm{a}}$ & $0.076^{\mathrm{a}}$ & $0.317^{\mathrm{a}}$ & $0.090^{\mathrm{a}}$ & $0.291^{\mathrm{a}}$ & $0.082^{\mathrm{a}}$ \\
\hline & $(0.047)$ & $(0.009)$ & $(0.049)$ & $(0.010)$ & $(0.081)$ & $(0.020)$ & $(0.078)$ & $(0.019)$ \\
\hline Real GDP Growth ( $\mathrm{t}$ & $-14.371^{\mathrm{a}}$ & $-3.326^{\mathrm{a}}$ & $-17.462^{\mathrm{a}}$ & $-4.072^{\mathrm{a}}$ & $-29.597^{\mathrm{a}}$ & $-8.368^{\mathrm{a}}$ & $-27.389^{\mathrm{a}}$ & $-7.682^{\mathrm{a}}$ \\
\hline-1$)$ & $(2.636)$ & $(0.649)$ & $(2.770)$ & $(0.692)$ & $(4.136)$ & $(1.331)$ & (4.036) & $(1.282)$ \\
\hline \multirow[t]{2}{*}{ Private } & $0.289^{\mathrm{a}}$ & $0.061^{\mathrm{a}}$ & $0.207^{\mathrm{a}}$ & $0.045^{\mathrm{a}}$ & 0.128 & 0.035 & $0.223^{\mathrm{a}}$ & $0.059^{\mathrm{a}}$ \\
\hline & $(0.059)$ & $(0.011)$ & $(0.061)$ & $(0.013)$ & $(0.088)$ & $(0.023)$ & $(0.086)$ & $(0.022)$ \\
\hline \multirow[t]{2}{*}{ Dividend covenant } & $0.824^{\mathrm{a}}$ & $0.243^{\mathrm{a}}$ & $0.819^{\mathrm{a}}$ & $0.243^{\mathrm{a}}$ & $0.740^{\mathrm{a}}$ & $0.242^{\mathrm{a}}$ & $0.742^{\mathrm{a}}$ & $0.242^{\mathrm{a}}$ \\
\hline & $(0.043)$ & $(0.016)$ & $(0.045)$ & $(0.017)$ & $(0.067)$ & $(0.025)$ & $(0.065)$ & $(0.025)$ \\
\hline Financial covenants & $-0.329^{a}$ & $-0.067^{\mathrm{a}}$ & $-0.317^{\mathrm{a}}$ & -0.065 & $-0.211^{\mathrm{a}}$ & $-0.056^{\mathrm{a}}$ & $-0.236^{\mathrm{a}}$ & $-0.061^{\mathrm{a}}$ \\
\hline
\end{tabular}
infinitesimal change in each independent, continuous variable and, by default, the discrete change in the probability for dummy variables. These effects are evaluated at the mean values of the independent variable.

Table 3. Determinants of collateral 


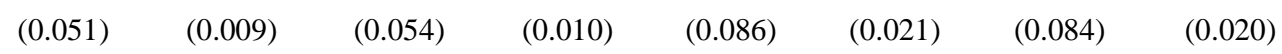

$\underline{\text { Loan Types }}$

\begin{tabular}{|c|c|c|c|c|c|c|c|c|}
\hline \multirow[t]{2}{*}{ Term Loans } & $0.220^{\mathrm{b}}$ & $0.049^{\mathrm{b}}$ & $0.270^{\mathrm{b}}$ & $0.060^{\mathrm{b}}$ & 0.156 & 0.043 & 0.148 & 0.041 \\
\hline & $(0.112)$ & $(0.024)$ & $(0.117)$ & $(0.025)$ & $(0.172)$ & $(0.046)$ & $(0.166)$ & $(0.044)$ \\
\hline \multirow[t]{2}{*}{ Day facility } & $-0.809^{\mathrm{a}}$ & $-0.249^{\mathrm{a}}$ & $-0.731^{\mathrm{a}}$ & $-0.222^{\mathrm{a}}$ & $-0.745^{\mathrm{a}}$ & $-0.253^{\mathrm{a}}$ & $-0.788^{a}$ & $-0.268^{\mathrm{a}}$ \\
\hline & $(0.125)$ & $(0.047)$ & $(0.131)$ & $(0.048)$ & $(0.195)$ & $(0.075)$ & $(0.189)$ & $(0.073)$ \\
\hline \multirow[t]{3}{*}{ Bridge loans } & $-0.659^{a}$ & $-0.201^{\mathrm{a}}$ & $-0.634^{\mathrm{a}}$ & $-0.193^{\mathrm{a}}$ & $-0.957^{\mathrm{a}}$ & $-0.345^{\mathrm{a}}$ & $-0.932^{\mathrm{a}}$ & $-0.334^{\mathrm{a}}$ \\
\hline & $(0.151)$ & $(0.055)$ & $(0.158)$ & $(0.058)$ & $(0.235)$ & $(0.092)$ & $(0.225)$ & $(0.089)$ \\
\hline & 0.340 & 0.065 & 0.261 & 0.053 & $-1.198^{\mathrm{a}}$ & $-0.440^{\mathrm{a}}$ & 0.151 & 0.040 \\
\hline Other loans & $(0.362)$ & $(0.056)$ & $(0.332)$ & $(0.057)$ & $(0.458)$ & $(0.170)$ & (1.072) & $(0.262)$ \\
\hline \multirow[t]{2}{*}{ Revolvers } & -0.129 & -0.030 & -0.084 & -0.019 & $-0.240^{\mathrm{a}}$ & $-0.067^{\mathrm{a}}$ & -0.238 & -0.066 \\
\hline & $(0.111)$ & $(0.025)$ & $(0.116)$ & $(0.027)$ & $(0.175)$ & $(0.049)$ & $(0.169)$ & $(0.047)$ \\
\hline \multirow[t]{2}{*}{ Revolver term loans } & -0.194 & -0.049 & -0.155 & -0.039 & $-0.162^{\mathrm{a}}$ & $-0.049^{\mathrm{a}}$ & -0.168 & -0.050 \\
\hline & $(0.142)$ & $(0.039)$ & $(0.148)$ & $(0.040)$ & $(0.245)$ & $(0.078)$ & $(0.241)$ & $(0.077)$ \\
\hline \multicolumn{9}{|l|}{ Loan Purposes } \\
\hline \multirow[t]{2}{*}{ Acquisition facility } & -0.325 & -0.088 & -0.330 & 0.090 & $-0.861^{\mathrm{a}}$ & $-0.309^{\mathrm{a}}$ & -0.873 & -0.313 \\
\hline & $(0.370)$ & $(0.114)$ & $(0.346)$ & $(0.107)$ & $(0.617)$ & $(0.246)$ & $(0.624)$ & $(0.248)$ \\
\hline \multirow[t]{2}{*}{ Recapitalisation-on } & $0.504^{\mathrm{a}}$ & $0.089^{\mathrm{a}}$ & $0.506^{\mathrm{a}}$ & $0.090^{\mathrm{a}}$ & 0.639 & 0.136 & $0.661^{\mathrm{a}}$ & $0.138^{\mathrm{a}}$ \\
\hline & $(0.124)$ & $(0.0163)$ & $(0.129)$ & $(0.017)$ & $(0.150)$ & $(0.024)$ & $(0.150)$ & $(0.023)$ \\
\hline \multirow[t]{2}{*}{ Takeover } & $0.138^{\mathrm{a}}$ & $0.030^{\mathrm{a}}$ & $0.120^{\mathrm{b}}$ & $0.027^{\mathrm{b}}$ & 0.171 & 0.046 & $0.180^{\mathrm{b}}$ & $0.048^{\mathrm{b}}$ \\
\hline & $(0.052)$ & $(0.0109)$ & $(0.053)$ & $(0.011)$ & $(0.076)$ & $(0.020)$ & $(0.074)$ & $(0.019)$ \\
\hline \multirow[t]{2}{*}{ Working Capital } & $-0.305^{\mathrm{a}}$ & $-0.776^{\mathrm{a}}$ & $-0.299^{\mathrm{a}}$ & $-0.077^{\mathrm{a}}$ & $-0.174^{\mathrm{a}}$ & $-0.052^{\mathrm{a}}$ & $-0.177^{\mathrm{a}}$ & $-0.052^{\mathrm{a}}$ \\
\hline & $(0.042)$ & $(0.012)$ & $(0.044)$ & $(0.013)$ & $(0.067)$ & $(0.021)$ & $(0.066)$ & $(0.021)$ \\
\hline \multirow[t]{2}{*}{ Capital Expenditure } & $-0.359^{c}$ & $-0.983^{c}$ & $-0.411^{b}$ & $-0.116^{b}$ & $-0.408^{\mathrm{a}}$ & $-0.133^{\mathrm{a}}$ & -0.391 & -0.126 \\
\hline & $(0.208)$ & $(0.0652)$ & $(0.188)$ & $(0.061)$ & $(0.296)$ & $(0.107)$ & $(0.316)$ & $(0.114)$ \\
\hline \multirow[t]{2}{*}{ CP Backup } & $-1.014^{\mathrm{a}}$ & $-0.333^{\mathrm{a}}$ & $-0.947^{\mathrm{a}}$ & $-0.308^{\mathrm{a}}$ & $-0.745^{\mathrm{a}}$ & $-0.258^{\mathrm{a}}$ & $-0.755^{\mathrm{a}}$ & $-0.259^{\mathrm{a}}$ \\
\hline & $(0.091)$ & $(0.0361)$ & $(0.095)$ & $(0.037)$ & $(0.116)$ & $(0.046)$ & $(0.112)$ & $(0.044)$ \\
\hline \multirow[t]{2}{*}{ LBO } & $0.548^{\mathrm{c}}$ & $0.962^{\mathrm{c}}$ & $0.485^{\mathrm{b}}$ & $0.089^{b}$ & 0.094 & 0.026 & 0.150 & 0.040 \\
\hline & $(0.215)$ & $(0.0243)$ & $(0.216)$ & $(0.027)$ & $(0.228)$ & $(0.059)$ & $(0.229)$ & $(0.056)$ \\
\hline \multirow[t]{2}{*}{ Corporate Purpose } & $-0.325^{\mathrm{a}}$ & $-0.836^{\mathrm{a}}$ & $-0.280^{\mathrm{a}}$ & $-0.072^{a}$ & $-0.296^{\mathrm{a}}$ & $-0.090^{\mathrm{a}}$ & $-0.336^{\mathrm{a}}$ & $-0.103^{\mathrm{a}}$ \\
\hline & $(0.042)$ & $(0.012)$ & $(0.043)$ & $(0.012)$ & $(0.062)$ & $(0.021)$ & $(0.061)$ & $(0.021)$ \\
\hline Observations & 20,757 & 20,757 & 19,787 & 19,787 & 9,754 & 9,754 & 10,053 & 10,053 \\
\hline Pseudo $\mathrm{R}^{2}$ & 0.376 & 0.376 & 0.398 & 0.398 & 0.523 & 0.523 & 0.512 & 0.5123 \\
\hline Log Likelihood & -7098.29 & -7098.29 & -6600.27 & -6600.27 & -2905.85 & -2905.85 & -30422.68 & -30422.66 \\
\hline Chi-Square & $2398.76^{\mathrm{a}}$ & $2398.76^{\mathrm{a}}$ & $2282.21^{\mathrm{a}}$ & $2282.21^{\mathrm{a}}$ & $1711.43^{\mathrm{a}}$ & $1711.43^{\mathrm{a}}$ & $1761.90^{\mathrm{a}}$ & $1761.90^{\mathrm{a}}$ \\
\hline
\end{tabular}

Note: This table provides results from probit regressions of the determinants of the use of collateral. The marginal effect is the actual change in the likelihood value of the use of collateral in response to changes in the independent variables. The dependent variable is equal to 1 if the loan is secured, zero otherwise. The independent variables are the credit rating of the borrower expressed in numbers defined in Table 2, the natural log of the total sales of the borrower in year $\mathrm{t}$ (Sales), the natural log of the total number of lenders participating in the syndicated loan (Number of Lenders), the term to maturity of the loan in number of months (Maturity), the natural log of the loan size (Size), the cumulative number of loans raised by the borrower (Frequency of Borrowing), the number of tranches or facilities in a deal ( Number of Tranches), the rate of growth real gross domestic product one year prior to 
when the loan is raised (real GDP growth at year t-1), a dummy variable equal 1 is the borrower is a private firm, zero otherwise ( Private), a dummy variable equal 1 if there is dividend restrictions, zero otherwise (Dividend covenant), a dummy variable equal 1 equal 1 if there are financial covenants, zero otherwise (Financial covenants), Term loan, Day facility, Acquisitions facility, Bridge loans, Other loans, Revolver, Revolver term loan are binary variables for the types of the loan, Recapitalization, Takeover, Working capital, Capital expenditure, Commercial paper back up, LBO, Corporate purpose are binary variables for the purposes of the loans. Inverse Mills ratio is from the Probit model estimated in table 5. The estimation includes dummy variables for the 50 states (region) of the borrower, the industry of the borrower based on the two digits SIC codes and the year the loan is made. These dummy variables are not reported. Standard errors are Heteroskedasticity robust, clustered at the firm level. Standard errors are in parenthesis. The notation ${ }^{\mathrm{a}},{ }^{\mathrm{b}},{ }^{\mathrm{c}}$, denote statistical significance at the levels $1 \%, 5 \%$, and $10 \%$, respectively.

Based on these results, it appears that most of the variables are significantly associated with the likelihood of the use of collateral in the syndicated loans. The maturity of the loan has a positive effect on the likelihood of the use of collateral. This is consistent with the reduction of asset substitution problem (Jackson \& Kronman, 1979), with the reduction of the effect of adverse events on the borrowers over longer periods and with value preservation of the collateral for the lender in the long run (Mann, 1997). The size of the loan has a negative impact on the likelihood of the use of collateral. This supports the argument that larger loans are subject to more rigorous screening to reduce information asymmetry resulting in a lower credit risk (Berger \& Udell, 1990; Booth, 1992). Output growth rate as measured by the real GDP growth rate is negatively related to the likelihood of the use of collateral in accordance with Jimenez et al. (2006). (Note 5) This is consistent with the argument that borrowers will likely be asked to pledge collateral during economic downturns. The number of lenders decreases with the likelihood of the use of collateral which supports the argument that when more quality information is available about a borrower and the borrower is transparent, more lenders join the syndicate (Lee \& Mullineaux, 2004; Sufi, 2005). The coefficient on dividend covenants is positive while the coefficient on financial covenants is negative. The existence of dividend restrictions increases the likelihood of the use of collateral while financial covenants decrease it. This suggests that each of these covenants plays a different role in syndicated loans. Dividends covenants are negative covenants which complement the role of collateral. Also, a dividend restriction is not binding unless the borrower is a dividend payer. Financial covenants are stronger and are a substitute to collateral as they impose many current restrictions on the operations and finances of the borrower. The borrower must maintain quarterly compliance with these covenants or suffer a technical default on the loan agreement. As for the experience of borrowing, we find that the more the borrower taps the syndicated loan market the higher is the likelihood of the use of collateral, which supports the argument of saturation of debt capacity. The size of the firm as proxied by the level of sales has a negative coefficient. This is consistent with the argument that larger firms are more transparent, reducing the need for collateral.

Credit rating has a negative coefficient. A higher credit rating lowers the probability of the use of collateral. It reduces the credit risk of the borrower hence reducing the need to pledge collateral. (Note 6) Measures associated with loan type show that term loan coefficient is positive, suggesting that term loans are forward looking loans and need further monitoring thus the need to pledge collateral. Bridge loans and 364-day facilities have negative coefficients. The short term and transitory nature of these loans does not necessitate the pledging of collateral. The rest of the loan types are not significant. Measures of loan purposes associated with an increase in leverage such as LBO, recapitalization and takeover have positive coefficients which are in accordance with the argument that increasing debt is associated with the need of more monitoring thus pledging of collateral. Loans used for purposes such as general corporate purpose, capital expenditure and CP back up have negative coefficients. These are traditional and non-speculative loans, so they do not require pledging collateral. (Note 7)

\subsection{Determinants of Loan Yield Spread}

In this section we explore the factors that affect the spread over LIBOR on secured and non-secured syndicated loans. We examine how the variables in model (1) affect the spread on syndicated loans. The decision to secure a loan is not separate from that of fixing the yield spread. The collateral will be pledged to mitigate the problem of adverse selection and of moral hazard faced by the lenders when granting a loan. In the adverse selection problem under asymmetric information high quality borrowers will pledge collateral to signal their quality and thus reduce interest rates. In the moral hazard problem where the risk characteristics of borrowers are known but their actions are not observed low quality borrowers will pledge collateral to reduce risk premium.

Due to the interdependence between the decision to use collateral and determination of the spread on a loan, we use an econometric approach (Heckman, 1976; Lee 1978) to detect and correct for selection bias. This approach was recently used by Booth and Booth (2006). The approach consists of two stages. In the first stage, we estimate the 
probability of the use of collateral using the probit model (1). The estimated parameters from this model are then used to construct consistent estimates of the inverse Mills ratio term, also called a "control function", to control for selection bias. In the second stage, we estimate the spread by using OLS models (2) and (3) below. The OLS models include all the independent variables used in the probit model and the constructed inverse Mills ratio. The estimates are unbiased, consistent and asymptotically normal. The unbiased estimates of the spreads for the secured and non-secured samples can be used to estimates the expected differences in these spreads. Estimation by OLS equations (2) and (3) without inverse Mills ratio is inappropriate because the error terms may be correlated with the state or region variable $\eta_{i}$ due to the presence of self-selection bias, which would result in non-zero expected values. If this correlation is not accounted for in the estimation models, inconsistent parameter estimates are obtained. We estimate the spread for secured syndicate loans by the model

$$
\begin{aligned}
\text { Spread }_{\mathrm{sec} i}=\alpha_{s 0} & +\alpha_{s 1} \text { Size }_{i}+\alpha_{s 2} \text { Term }_{i}+\alpha_{s 3} \text { Rating }_{i}+\alpha_{s 4} \text { Tranches }_{i} \\
& +\alpha_{s 5} \text { Priv }_{i}+\alpha_{s 6} \text { DivCov }_{i}+\alpha_{s 7} \text { FinCov }_{i}+\alpha_{s 8} \text { Exp }_{i} \\
& +\alpha_{s 9} \text { Sales }_{i}+\alpha_{s 10} \text { Lenders }_{i}+\alpha_{s 11} \text { Econ }_{i}+\alpha_{s 12} \text { LType }_{i} \\
& +\alpha_{s 13} \text { LPurpose }_{i}+\lambda_{s i} \text { invmills }_{s i}+\tau_{s i}
\end{aligned}
$$

As for unsecured loans, we estimate the spread by the model

$$
\begin{aligned}
\text { Spread }_{u n \mathrm{sec} i}=\alpha_{s 0} & +\alpha_{u s 1} \text { Size }_{i}+\alpha_{u s 2} \text { Term }_{i}+\alpha_{u s 3} \text { Rating }_{i}+\alpha_{u s 4} \text { Tranches }_{i} \\
& +\alpha_{u s 5} \text { Priv }_{i}+\alpha_{u s 6} \text { DivCov }_{i}+\alpha_{u s 7} \text { FinCov }_{i}+\alpha_{u s 8} \text { Exp }_{i} \\
& +\alpha_{u s 9} \text { Sales }_{i}+\alpha_{u s 10} \text { Lenders }_{i}+\alpha_{u s 11} \text { Econ }_{i}+\alpha_{u s 12} \text { LType }_{i} \\
& +\alpha_{u s 13} \text { LPurpose }_{i}+\lambda_{u s i} \text { invmills }_{u s i}+\tau_{u s i}
\end{aligned}
$$

where

$$
\text { invmills }_{s i}=\frac{f\left(\phi_{i}\right)}{F\left(\phi_{i}\right)} \quad \text { and } \quad \text { invmills }_{u i}=\frac{f\left(\phi_{i}\right)}{1-F\left(\phi_{i}\right)}
$$

and $f$ is the standard normal probability function of $\phi, F$ is the cumulative density probability function of $\phi$, and $\phi$ is the prediction from the reduced form the probit model

$$
\begin{aligned}
\phi_{i}=\beta_{0} & +\beta_{1} \text { Size }_{i}+\beta_{2} \text { Term }_{i}+\beta_{3} \text { Rating }_{i}+\beta_{4} \text { NTranches }_{i} \\
& +\beta_{5} \text { Priv }+\beta_{6}{\text { Div } \operatorname{cov}_{i}+\beta_{7} \text { Fin }_{\text {Cov }}+\beta_{8} \text { Exp }_{j}+\beta_{9} \text { Sales }_{j}} \\
& +\beta_{10} \text { Nlenders }_{i j}+\beta_{11} \text { Econ }+\beta_{12} \text { Ltype }_{i}+\beta_{13} \text { Lpurpose }_{i}
\end{aligned}
$$

These inverse Mills variables are monotonically decreasing functions of the probability that an observation is selected into the respective sample and is the expected value of the error term $\eta_{i}$ given a truncated normal distribution. That is, it is the expected value of the borrower's private information about the decision or requirement to secure the loan, conditional on the observed characteristics of the loan and the borrower. The coefficients of the inverse Mills variables represent the covariance between error terms of the spread equations and the error term of the probit equation. A significant coefficient of the inverse Mills ratio is the condition for the presence of self-selection bias that the spread is affected by the decision to pledge collateral. The sign of the coefficient gives us the direction of the selection bias. Specifically, a negative coefficient would provide support to the argument that pledging collateral decreases the spread on the syndicated loan while a positive coefficient implies that pledging collateral increases the loan spread.

Table 4 provides the regression results of the determinants of syndicated loan spreads specified in equation 2 for secured loan sample and equation 3 for unsecured loan sample. The results indicate that most of the variables are significantly associated with the spread on secured and unsecured syndicated loans. 
Table 4. Determinants of the yield spread on syndicated loans

\begin{tabular}{|c|c|c|c|c|c|c|c|c|}
\hline & \multicolumn{2}{|c|}{ Specification 1} & \multicolumn{2}{|c|}{ Specification 2} & \multicolumn{2}{|c|}{ Specification 3} & \multicolumn{2}{|c|}{ Specification 4} \\
\hline & Secured & Unsec. & Secured & Unsec. & Secured & Unsec. & Secured & Unsec. \\
\hline \multicolumn{9}{|l|}{ Loan } \\
\hline \multicolumn{9}{|l|}{ Characteristic } \\
\hline \multirow[t]{2}{*}{ Credit Rating } & & & & & $-7.169^{\mathrm{a}}$ & $-9.695^{\mathrm{a}}$ & $-7.193^{\mathrm{a}}$ & $-9.824^{\mathrm{a}}$ \\
\hline & & & & & $(0.593)$ & (1.589) & $(0.602)$ & $(1.725)$ \\
\hline \multirow[t]{2}{*}{ Sales } & & & $-2.730^{\mathrm{a}}$ & $-12.421^{\mathrm{a}}$ & 0.059 & $-9.556^{\mathrm{a}}$ & & \\
\hline & & & (1.019) & $(1.750)$ & (1.273) & $(2.305)$ & & \\
\hline Number of & $-3.965^{\mathrm{a}}$ & $-4.493^{b}$ & $-4.555^{\mathrm{a}}$ & -2.873 & $-9.529^{\mathrm{a}}$ & -3.157 & $-9.639^{a}$ & -3.588 \\
\hline lenders & (1.131) & $(2.160)$ & $(1.135)$ & (1.979) & $(1.410)$ & $(2.515)$ & (1.407) & $(2.590)$ \\
\hline \multirow[t]{2}{*}{ Term } & $-0.598^{\mathrm{a}}$ & $-0.346^{\mathrm{a}}$ & $-0.632^{\mathrm{a}}$ & $-0.326^{\mathrm{a}}$ & $-0.291^{\mathrm{a}}$ & -0.068 & $-0.262^{a}$ & -0.064 \\
\hline & $(0.060)$ & $(0.094)$ & $(0.062)$ & $(0.089)$ & $(0.095)$ & $(0.106)$ & $(0.093)$ & $(0.116)$ \\
\hline \multirow[t]{2}{*}{ Size } & $-11.341^{\mathrm{a}}$ & $-17.998^{\mathrm{a}}$ & $-10.776^{\mathrm{a}}$ & $-10.052^{\mathrm{a}}$ & $-14.577^{\mathrm{a}}$ & $-9.908^{\mathrm{a}}$ & $-14.449^{\mathrm{a}}$ & $-14.332^{\mathrm{a}}$ \\
\hline & $(1.175)$ & $(2.698)$ & $(1.140)$ & (1.908) & $(1.598)$ & $(2.832)$ & $(1.575)$ & $(3.771)$ \\
\hline \multirow{2}{*}{$\begin{array}{l}\text { Frequency of } \\
\text { borrowing }\end{array}$} & $0.586^{\mathrm{b}}$ & $1.305^{\mathrm{a}}$ & $1.002^{\mathrm{a}}$ & $1.947^{\mathrm{a}}$ & 0.187 & $1.998^{\mathrm{a}}$ & 0.165 & $1.618^{\mathrm{a}}$ \\
\hline & $(0.302)$ & $(0.528)$ & $(0.316)$ & $(0.588)$ & $(0.372)$ & $(0.683)$ & $(0.367)$ & $(0.619)$ \\
\hline \multirow{2}{*}{$\begin{array}{l}\text { Number of } \\
\text { tranches }\end{array}$} & $5.674^{\mathrm{a}}$ & 1.318 & $8.128^{\mathrm{a}}$ & 4.016 & $9.980^{\mathrm{a}}$ & 3.077 & $9.823^{\mathrm{a}}$ & 0.670 \\
\hline & (1.084) & $(3.154)$ & (1.157) & $(3.227)$ & $(1.587)$ & $(4.647)$ & (1.535) & (4.377) \\
\hline \multirow[t]{2}{*}{ Private } & $11.342^{\mathrm{a}}$ & $14.597^{\mathrm{a}}$ & $14.517^{\mathrm{a}}$ & $11.597^{\mathrm{a}}$ & $13.503^{\mathrm{a}}$ & 4.941 & $12.910^{\mathrm{a}}$ & 8.056 \\
\hline & $(2.169)$ & $(4.439)$ & $(2.190)$ & $(4.151)$ & $(2.885)$ & $(4.722)$ & $(2.850)$ & $(5.124)$ \\
\hline \multirow{4}{*}{$\begin{array}{l}\text { Dividend } \\
\text { covenants } \\
\text { Financial } \\
\text { covenants }\end{array}$} & $-11.744^{\mathrm{a}}$ & $25.317^{\mathrm{a}}$ & -1.319 & $28.496^{\mathrm{a}}$ & 7.070 & $28.920^{\mathrm{a}}$ & 2.637 & $26.314^{\mathrm{a}}$ \\
\hline & $(4.902)$ & $(7.209)$ & (4.903) & $(6.788)$ & $(6.712)$ & $(9.197)$ & (6.589) & $(9.235)$ \\
\hline & $-11.887^{\mathrm{a}}$ & -4.017 & $-14.599^{\mathrm{a}}$ & $-7.940^{\mathrm{b}}$ & $-13.515^{\mathrm{a}}$ & $-9.407^{b}$ & $-13.247^{\mathrm{a}}$ & $-8.129^{b}$ \\
\hline & $(3.374)$ & $(4.234)$ & $(3.474)$ & $(4.200)$ & $(5.133)$ & $(3.914)$ & $(5.160)$ & (4.008) \\
\hline \multirow{3}{*}{$\begin{array}{l}\text { GDP Growth } \\
(\mathrm{t}-1) \\
\text { Loan Types }\end{array}$} & $-3007.55^{\mathrm{a}}$ & $-1789.15^{\mathrm{a}}$ & $-3144.64^{\mathrm{a}}$ & $-1963.42^{\mathrm{a}}$ & $-3705.74^{\mathrm{a}}$ & $-2902.08^{a}$ & $-3668.35^{\mathrm{a}}$ & $-2679.41^{a}$ \\
\hline & $(154.712)$ & $(200.957)$ & $(158.744)$ & $(210.224)$ & $(217.671)$ & $(409.876)$ & $(216.209)$ & $(388.463)$ \\
\hline & & & & & & & & \\
\hline \multirow[t]{2}{*}{ Term Loans } & $19.735^{\mathrm{a}}$ & 16031 & $22.520^{\mathrm{a}}$ & $21.091^{\mathrm{c}}$ & $29.615^{\mathrm{a}}$ & 13.829 & $29.311^{\mathrm{a}}$ & 11.742 \\
\hline & $(6.742)$ & $(12.480)$ & (7.103) & (11.646) & $(7.672)$ & (13.116) & $(7.481)$ & (13.377) \\
\hline \multirow[t]{2}{*}{ Day facility } & $-50.881^{\mathrm{a}}$ & $-54.127^{\mathrm{a}}$ & $-59.363^{\mathrm{a}}$ & $-48.993^{\mathrm{a}}$ & $-53.329^{\mathrm{a}}$ & $-49.792^{\mathrm{a}}$ & $-51.874^{\mathrm{a}}$ & $-49.807^{\mathrm{a}}$ \\
\hline & $(9.549)$ & $(13.357)$ & $(9.788)$ & (12.157) & (11.812) & (14.867) & (11.872) & (15.479) \\
\hline \multirow[t]{2}{*}{ Bridge loans } & $64.919^{a}$ & $70.077^{\mathrm{a}}$ & $52.914^{\mathrm{a}}$ & $77.221^{\mathrm{a}}$ & $108.258^{\mathrm{a}}$ & $63.014^{\mathrm{b}}$ & $102.190^{\mathrm{a}}$ & $63.071^{\mathrm{b}}$ \\
\hline & (15.927) & $(22.210)$ & (16.801) & $(21.746)$ & $(26.515)$ & $(25.803)$ & $(24.501)$ & $(25.737)$ \\
\hline \multirow[t]{2}{*}{ Other loans } & -7.480 & 81.404 & -21.137 & 79.719 & 40.270 & 34.458 & 61.845 & 68.547 \\
\hline & (23.872) & $(59.570)$ & (20.984) & (59.679) & $(26.126)$ & $(60.052)$ & $(48.351)$ & (54.358) \\
\hline \multirow[t]{2}{*}{ Revolvers } & $-26.444^{\mathrm{a}}$ & -17.145 & $-25.355^{\mathrm{a}}$ & -15.071 & $-19.317^{\mathrm{a}}$ & $-24.502^{b}$ & $-20.835^{\mathrm{a}}$ & $-23.591^{\mathrm{a}}$ \\
\hline & $(6.682)$ & (11.507) & $(7.042)$ & (10.469) & $(7.533)$ & (11.602) & $(7.371)$ & (11.926) \\
\hline Revolver term & $-21.231^{\mathrm{a}}$ & -15608 & $-19.667^{b}$ & -15.011 & -6.333 & -21.314 & -8.037 & -22.081 \\
\hline loans & $(8.640)$ & (12.988) & $(9.008)$ & (12.000) & (12.021) & (13.527) & (11.834) & (13.820) \\
\hline
\end{tabular}


Loan

Purposes

$\begin{array}{lccccccccc}\text { Acquisition } & -20.798 & 89.689 & -19.171 & 101.598^{\mathrm{c}} & 19.199 & 8.402 & 18.655 & 4.756 \\ \text { facility } & (17.222) & (61.211) & (17.511) & (58.951) & (33.225) & (23.207) & (33.281) & (24.053) \\ \text { Recapitalizati } & 6.698 & 8.420 & 9.916^{\mathrm{b}} & 9.920 & 10.859^{\mathrm{c}} & 1.139 & 10.583^{\mathrm{c}} & -2.775 \\ \text { on } & (4.658) & (9.425) & (4.657) & (8.497) & (5.903) & (10.701) & (5.826) & (11.109) \\ \text { Takeover } & -3.654^{\mathrm{c}} & 10.499^{\mathrm{b}} & -2.222 & 10.046^{\mathrm{b}} & 2.791 & 7.138 & 1.362 & 6.629 \\ & (2.256) & (4.70) & (2.299) & (4.570) & (2.945) & (5.089) & (2.907) & (5.105) \\ \text { Working } & -4.138 & -14.375^{\mathrm{a}} & -6.046^{\mathrm{c}} & -14.578^{\mathrm{a}} & -0.111 & -18.002^{\mathrm{a}} & -0.133 & -17.343^{\mathrm{a}} \\ \text { Capital } & (3.096) & (3.856) & (3.142) & (3.780) & (4.484) & (4.074) & (4.454) & (4.045) \\ \text { Capital } & -23.008^{\mathrm{b}} & -21.369^{\mathrm{a}} & -26.483^{\mathrm{b}} & -20.265^{\mathrm{a}} & -20.162 & -23.283^{\mathrm{b}} & -20.540 & -25.257^{\mathrm{a}} \\ \text { Expenditure } & (11.197) & (7.822) & (11.337) & (7.563) & (13.680) & (9.672) & (13.829) & (10.164) \\ \text { Commercial } & -8.817 & -42.169^{\mathrm{a}} & -21.229^{\mathrm{c}} & -42.037^{\mathrm{a}} & -26.961^{\mathrm{b}} & -42.053^{\mathrm{a}} & -30.270^{\mathrm{b}} & -40.330^{\mathrm{a}} \\ \text { Paper Backup } & (11.727) & (9.176) & (11.504) & (8.223) & (13.648) & (9.761) & (13.207) & (9.745) \\ \text { LBO } & 23.275^{\mathrm{a}} & 203.081^{\mathrm{a}} & 24.378^{\mathrm{a}} & 197.693^{\mathrm{a}} & 19.089^{\mathrm{a}} & 164.576^{\mathrm{a}} & 19.326^{\mathrm{a}} & 171.450^{\mathrm{a}} \\ & (2.978) & (42.752) & (2.974) & (41.861) & (3.991) & (53.776) & (4.010) & (54.181) \\ \text { Corporate } & 0.587 & -18.264^{\mathrm{a}} & -0.537 & -15.739^{\mathrm{a}} & -1.668 & -14.169^{\mathrm{a}} & -1.854 & -15.471^{\mathrm{a}} \\ \text { Purpose } & (3.274) & (3.681) & (3.291) & (3.384) & (4.477) & (4.698) & (4.500) & (5.051) \\ \text { Inverse Mills } & -78.232^{\mathrm{a}} & 18.952^{\mathrm{c}} & -57.761^{\mathrm{a}} & 23.797^{\mathrm{b}} & -26.560^{\mathrm{a}} & 31.584^{\mathrm{b}} & -26.606^{\mathrm{a}} & 27.200^{\mathrm{c}} \\ \text { ratio } & (7.664) & (11.546) & (7.393) & (10.714) & (8.377) & (15.325) & (8.829) & (15.428)\end{array}$

Number of

$\begin{array}{lcccccccc}\text { Obs. } & 15,266 & 4,851 & 4,473 & 4,730 & 6,543 & 3,049 & 6,783 & 3,099 \\ \text { adjusted R } & 0.248 & 0.346 & 0.250 & 0.372 & 0.337 & 0.447 & 0.335 & 0.438 \\ \text { F statistic } & 88.140^{\mathrm{a}} & 33.35^{\mathrm{a}} & 84.030^{\mathrm{a}} & 34.60^{\mathrm{a}} & 52.520^{\mathrm{a}} & 26.820^{\mathrm{a}} & 52.470^{\mathrm{a}} & 26.990^{\mathrm{a}}\end{array}$

Note. This table provides results of the selection bias correction regressions of the determinants of loan yield spread for secured and unsecured syndicated loans. The independent variables are the credit rating of the borrower expressed in numbers defined in Table 2 , the natural $\log$ of the total sales of the borrower in year $\mathrm{t}$ (Sales), the natural log the total number of lenders participating in the syndicated loan (Number of Lenders), the term to maturity of the loan in number of months (Maturity), the natural log of the loan size (Size), the cumulative number of loans raised by the borrower (Frequency of Borrowing), the number of tranches or facilities in a deal (Number of Tranches), the growth rate of real gross domestic product one year prior to when the loan is raised (GDP growth at year t-1), a dummy variable equal 1 is the borrower is a private firm, zero otherwise ( Private), a dummy variable equal 1 if there is dividend restrictions, zero otherwise (Dividend Covenant), a dummy variable equal 1 equal 1 if there are financial covenants, zero otherwise (Financial covenants), Term loan, Day facility, Acquisitions facility, Bridge loans, Other loans, Revolver, Revolver term loan are binary variables for the types of the loan, Recapitalization, Takeover, Working capital, Capital expenditure, Commercial paper back up, LBO, Corporate purpose are binary variables for the purposes of the loans. Inverse Mills ratio is from the probit model estimated in table 5. The estimation includes dummy variables for the 50 states of the borrower, the industry of the borrower based on the two digits SIC codes and the year the loan is made. These dummy variables are not reported. White's (1980) Heteroskedasticity-consistent standard errors are in parenthesis. The notation ${ }^{\text {a b }}{ }^{\text {b }}{ }^{\mathrm{c}}$, denote statistical significance at the levels $1 \%, 5 \%$, and $10 \%$, respectively.

The negative coefficient of credit rating is in accordance with the theoretical result that the lower the default risk (the higher the rating) the lower the spread paid by the borrower. The negative coefficient of sales indicates that larger firms pay lower yield. As Sales is a proxy for firm size, smaller firms have higher risk due to higher information costs, while larger firms are likely to be more diversified, which implies lower risk and lower expected bankruptcy 
costs. This is consistent with the findings of Peterson and Rajan (1994), who posit that adverse selection and moral hazard may have more influence on small and young corporate borrowers.

The negative coefficient of number of lenders indicates that the larger the number of lenders in the syndicate the lower the spread paid by borrowers. Increasing the size of a loan syndicate could reduce each lender's exposure to firm-specific risk, this would also serve to discourage strategic default by the borrower (Esty \& Megginson, 2003). The positive coefficient of the frequency of borrowing suggests that the more the borrower taps the syndicated loan market the lower is the debt capacity associated with the loan market.

The negative coefficient of maturity indicates that the spread decreases with maturity. This is in accordance with the argument that lenders, when structuring their portfolios, prefer granting short term loans to riskier borrowers (credit quality hypothesis) instead of offering longer-term loans at higher rates. At the same time, lower risk borrowers signal their credit quality by taking short-term loans (Flannery, 1986; Kale \& Noe, 1990), suggesting a negative relation between spreads and maturity. Empirical work by Dennis, Nandy, and Sharpe (2000), and Berger and Udell (1990) find a negative maturity effect on loan spread.

The negative coefficient of size indicates that spread decreases as size increases. This is in accordance with the theory that considers size of the issue as a proxy for the liquidity and marketability of the issue. Larger issues increase the probability that there is an active market for the issue, therefore lowering the spread. Besides liquidity, this may reflect economies of scale considered by lenders in information-gathering, screening and monitoring costs.

The yield spread increases with the number of tranches in the loan deal. It decreases with strong economic conditions; the higher the real GDP growth the lower is the yield spread. The spread increases when the borrower is a private firm. When it comes to covenants the spread decreases with the existence of financial covenants but for the dividend restriction covenants the results are mixed for the secured and unsecured loans. The spread increases when dividend restrictions exist. For loan types, the yield spread for term loans, decreases for a short-term 634-day facility and increases for a bridge loan. For loan purposes, the yield spread increases if the loan is for recapitalization or for LBO and decreases if the loan is for capital expenditure, working capital, or corporate purposes.

The coefficients of the inverse Mills ratios are significant for both the secured loan and unsecured loan models. For the secured loan model, it is negative and significant at the 1 percent level which means that pledging collateral decreases the loan spread and implies that the existence of collateral conveys additional and unobservable information about the borrower. For the unsecured loan model, the coefficient of the inverse Mills ratio is positive and significant at the 5 or 10 percent level depending on the specification, which means that pledging collateral is associated with higher loan spreads. Based on these results we notice that there is a simultaneity problem between the decision to pledge collateral and the decision to set the loan spread which needs to be corrected.

\subsection{Predictions of the Loan Spread}

We use the regressions in Table 4 to examine whether the decision to pledge collateral is consistent with lowering the spread or imposing higher spread. We compare the fitted values of the loan spread using the estimates from the selection biased corrected regressions (SBC) and the OLS regressions for the secured and unsecured samples.

Part 1 of Table 5 indicates that the actual loan spreads for secured loans are significantly higher than those for unsecured loans. The actual spread over LIBOR for the secured loan averages 264.4 basis points while for unsecured it is just 99.6 basis points. All the differences in mean spreads are significant at 1 percent level. 
Table 5. The expected average loan yield spread based on requirement to pledge collateral

\begin{tabular}{|c|c|c|c|c|c|c|c|c|c|c|c|c|}
\hline \multicolumn{5}{|c|}{ Part (1) } & \multicolumn{4}{|c|}{ Part (2) } & \multicolumn{4}{|c|}{ Part (3) } \\
\hline & & & & & \multicolumn{4}{|c|}{ Observations from Secured loans } & \multicolumn{4}{|c|}{ Observations from Unsecured loans } \\
\hline & \multirow{2}{*}{\multicolumn{2}{|c|}{$\begin{array}{l}\text { Number } \\
\text { of loans }\end{array}$}} & \multirow{2}{*}{\multicolumn{2}{|c|}{$\begin{array}{c}\text { Actual } \\
\text { loan spreads }\end{array}$}} & \multirow{2}{*}{\multicolumn{2}{|c|}{$\begin{array}{l}\text { Estimates } \\
\text { from OLS }\end{array}$}} & \multirow{2}{*}{\multicolumn{2}{|c|}{$\begin{array}{l}\text { Estimates } \\
\text { from SBC }\end{array}$}} & \multirow{2}{*}{\multicolumn{2}{|c|}{$\begin{array}{l}\text { Estimates } \\
\text { from OLS }\end{array}$}} & \multirow{2}{*}{\multicolumn{2}{|c|}{$\begin{array}{l}\text { Estimates } \\
\text { from SBC }\end{array}$}} \\
\hline & & & & & & & & & & & & \\
\hline Spec & Sec. & Uns & $\mathrm{SS}_{\mathrm{s}}$ & $\mathrm{US}_{\mathrm{u}}$ & $\mathrm{SS}_{\mathrm{s}}{ }^{a}$ & $\mathrm{SS}_{\mathrm{u}}{ }^{\mathrm{b}}$ & $\mathrm{SS}_{\mathrm{s}}^{\mathrm{c}}$ & $\mathrm{SS}_{\mathrm{u}}{ }^{\mathrm{d}}$ & $\mathrm{US}_{\mathrm{s}}{ }^{\mathrm{e}}$ & $\mathrm{US}_{\mathrm{u}}{ }^{\mathrm{f}}$ & $\mathrm{US}_{\mathrm{s}}{ }^{\mathrm{g}}$ & $\mathrm{US}_{\mathrm{u}}{ }^{\mathrm{h}}$ \\
\hline 1 & 24680 & 6668 & $\begin{array}{c}264.37 \\
(128.61)\end{array}$ & $\begin{array}{l}99.58 \\
(87.91)\end{array}$ & $\begin{array}{l}260.45 \\
(61.90)\end{array}$ & $\begin{array}{l}146.29 \\
(63.63)\end{array}$ & $\begin{array}{l}260.43 \\
(62.34)\end{array}$ & $\begin{array}{l}149.34 \\
(63.93)\end{array}$ & $\begin{array}{l}180.15 \\
(65.96)\end{array}$ & $\begin{array}{c}90.70 \\
(45.75)\end{array}$ & $\begin{array}{l}165.16 \\
(79.05)\end{array}$ & $\begin{array}{c}90.71 \\
(45.84)\end{array}$ \\
\hline 2 & 24680 & 6668 & $\begin{array}{c}264.37 \\
(128.61)\end{array}$ & $\begin{array}{l}99.58 \\
(87.91)\end{array}$ & $\begin{array}{l}260.20 \\
(62.14)\end{array}$ & $\begin{array}{l}151.34 \\
(64.07)\end{array}$ & $\begin{array}{l}260.15 \\
(62.37)\end{array}$ & $\begin{array}{l}156.11 \\
(65.14)\end{array}$ & $\begin{array}{l}175.53 \\
(66.15)\end{array}$ & $\begin{array}{c}90.71 \\
(47.25)\end{array}$ & $\begin{array}{l}162.89 \\
(77.02)\end{array}$ & $\begin{array}{c}90.74 \\
(47.44)\end{array}$ \\
\hline 3 & 24680 & 6668 & $\begin{array}{c}264.37 \\
(128.61)\end{array}$ & $\begin{array}{l}99.58 \\
(87.91)\end{array}$ & $\begin{array}{l}254.55 \\
(68.19)\end{array}$ & $\begin{array}{l}155.16 \\
(69.28)\end{array}$ & $\begin{array}{l}254.47 \\
(68.33)\end{array}$ & $\begin{array}{l}166.50 \\
(70.88)\end{array}$ & $\begin{array}{l}143.26 \\
(74.05)\end{array}$ & $\begin{array}{c}79.96 \\
(49.57)\end{array}$ & $\begin{array}{l}133.47 \\
(80.82)\end{array}$ & $\begin{array}{c}79.97 \\
(49.72)\end{array}$ \\
\hline 4 & 24680 & 6668 & $\begin{array}{c}264.37 \\
(128.61)\end{array}$ & $\begin{array}{l}99.58 \\
(87.91)\end{array}$ & $\begin{array}{l}254.96 \\
(68.25)\end{array}$ & $\begin{array}{l}151.94 \\
(69.22)\end{array}$ & $\begin{array}{l}254.88 \\
(68.38)\end{array}$ & $\begin{array}{l}160.71 \\
(69.91)\end{array}$ & $\begin{array}{l}144.71 \\
(72.87)\end{array}$ & $\begin{array}{c}79.77 \\
(48.80)\end{array}$ & $\begin{array}{l}135.12 \\
(79.33)\end{array}$ & $\begin{array}{c}79.78 \\
(48.93)\end{array}$ \\
\hline
\end{tabular}

Note: The four specifications (Spec 1, Spec 2, Spec 3, and Spec 4) are based on the regressions of table 6. The loan yield spread is measured by the spread over LIBOR which takes into accounts the fees paid by the borrower to the lenders expressed in basis points. OLS estimates are fitted from equation 3 and 4. SBA (Selectivity-Bias-Corrected) estimates are fitted from equations 5 adding the inverse Mills ratio as an independent variable. Standard deviations are in parenthesis. The differences in means between the secured and unsecured loan spreads are statistically significant at the 1 percent level.

${ }^{a}$ The average fitted value of the loan yield spread for the secured loans, using coefficient estimates from the OLS SECURED regression.

${ }^{\mathrm{b}}$ The average fitted values of the loan yield spread for the secured loans, using coefficient estimates from the OLS UNSECURED regression.

${ }^{c}$ The average fitted values of the loan yield spread for the secured loans, using coefficient estimates from the SBC SECURED regression.

${ }^{\mathrm{d}}$ The average fitted values of the loan yield spread for the secured loans, using coefficient estimates from the SBC UNSECURED regression.

${ }^{\mathrm{e}}$ The average fitted values of the loan yield spread for the unsecured loans, using coefficient estimates from the OLS SECURED regression.

${ }^{\mathrm{f}}$ The average fitted values of the loan yield spread for the unsecured loans, using coefficient estimates from the OLS UNSECURED regression.

${ }^{\mathrm{g}}$ The average fitted values of the loan yield spread for the unsecured loans, using coefficient estimates from the SBC SECURED regression.

${ }^{\mathrm{h}}$ The average fitted values of the loan yield spread for the unsecured loans, using coefficient estimates from the SBC spread UNSECURED regression.

Part 2 of table 5 reports the results for loans that were secured using the OLS without the inverse Mills ratio and SBC with the inverse Mills ratio regressions. We compare the expected value of the spread estimated from these models. $\operatorname{SSpread}_{\mathrm{s}}$ is the average fitted value of the loan spread using the coefficient estimates from the secured regressions for the sample of the loans that were secured. SSpread $_{u}$ is the average fitted value of the loan spread using the coefficient estimates from the unsecured regressions for the sample of the loans that were secured. Part 3 of table 5 reports the results for unsecured loans. In this part, USpread ${ }_{s}$ is the average fitted value of the loan spread using the coefficient estimates from the secured loan regressions for the sample of the loans that were unsecured. USpread $\mathrm{u}_{\mathrm{u}}$ is the average fitted value of the loan spread using the coefficient estimates from the unsecured regressions for the sample of the loans that were unsecured.

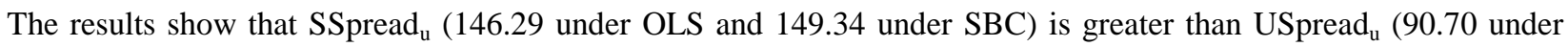
OLS and 90.71 under SBC). This means that borrowers who initially pledged collateral and switched to unsecured loans will still pay higher spread than the one paid by the unsecured borrowers. Also, USpread $\left(180.15\right.$ under OLS $_{\mathrm{s}}$ and 165.16 under SBC) is lower than $\operatorname{SSpread}_{\mathrm{s}}$ (260.45 under OLS and 260.43 under SBC). This means that 
borrowers who initially borrowed on unsecured basis will still pay less than those that borrowed on secured basis. This is in accordance with the moral hazard argument that risky borrowers will pledge collateral to reduce the cost of borrowing.

For robustness we report in Table 6 the same tests as in Table 5 for term loans, for loans with different sizes, and for loans issued by public and private firms using specification 1 . We find that for term loans, loans with sizes above or below 87 million, and loans raised by borrowers with credit rating greater than or equal to BBB or below BBB the actual yield spread is significantly higher for secured loans than those of unsecured ones. In addition, we find that for borrowers who get secured loans the yield spread they would pay if they switched to unsecured loans would be significantly higher than the yield spread paid by unsecured borrowers. These results hold for loans with different types and different sizes and for loans raised by borrowers with different credit ratings. They support the prediction of the moral hazard theory that high quality borrowers issue unsecured loans and low-quality borrowers issue secured loans and if they switch to unsecured they would still pay higher spread than the unsecured borrowers.

Table 6. The expected average loan yield spread based on requirement to pledge collateral

\begin{tabular}{|c|c|c|c|c|c|c|c|c|c|c|c|c|}
\hline & \multicolumn{4}{|c|}{ (1) } & \multicolumn{4}{|c|}{ (2) } & \multicolumn{4}{|c|}{ (3) } \\
\hline & & & & & Obs & ervations & $\mathrm{n}$ secured & oans & Observat & ons from & isecured lo & \\
\hline & \multicolumn{2}{|c|}{ Number of Loans } & \multicolumn{2}{|c|}{ Actual spread } & \multicolumn{2}{|c|}{ OLS estimates } & \multicolumn{2}{|c|}{ SBC estimates } & \multicolumn{2}{|c|}{ OLS estimates } & \multicolumn{2}{|c|}{ SBC estimates } \\
\hline & $\mathrm{Sec}$ & un & $\mathrm{SS}_{\mathrm{s}}$ & $\mathrm{US}_{\mathrm{u}}$ & $\mathrm{SS}_{\mathrm{s}}{ }^{\mathrm{a}}$ & $\mathrm{SS}_{\mathrm{u}}^{\mathrm{b}}$ & $\mathrm{SS}_{\mathrm{s}}^{\mathrm{c}}$ & $\mathrm{SS}_{\mathrm{u}}^{\mathrm{d}}$ & $\mathrm{US}_{\mathrm{s}}^{\mathrm{e}}$ & $\mathrm{US}_{\mathrm{u}}^{\mathrm{f}}$ & $\mathrm{US}_{\mathrm{s}}{ }^{\mathrm{g}}$ & $\mathrm{US}_{\mathrm{u}}{ }^{\mathrm{h}}$ \\
\hline All sample & 24680 & 6668 & $\begin{array}{l}264.37 \\
(128.61)\end{array}$ & $\begin{array}{l}99.58 \\
(87.91)\end{array}$ & $\begin{array}{l}260.45 \\
(61.90)\end{array}$ & $\begin{array}{l}146.29 \\
(63.63)\end{array}$ & $\begin{array}{l}260.43 \\
(62.34)\end{array}$ & $\begin{array}{l}149.34 \\
(63.93)\end{array}$ & $\begin{array}{l}180.15 \\
(65.96)\end{array}$ & $\begin{array}{l}90.70 \\
(45.75)\end{array}$ & $\begin{array}{l}165.16 \\
(79.05)\end{array}$ & $\begin{array}{l}90.71 \\
(45.84)\end{array}$ \\
\hline Term loans & 8943 & 622 & $\begin{array}{l}303.49 \\
(143.84)\end{array}$ & $\begin{array}{c}179.66 \\
(129.06)\end{array}$ & $\begin{array}{l}297.41 \\
(55.92)\end{array}$ & $\begin{array}{l}181.68 \\
(55.73)\end{array}$ & $\begin{array}{l}297.41 \\
(56.36)\end{array}$ & $\begin{array}{l}182.29 \\
(55.90)\end{array}$ & $\begin{array}{l}277.20 \\
(54.24)\end{array}$ & $\begin{array}{l}142.72 \\
(56.96)\end{array}$ & $\begin{array}{l}266.34 \\
(60.73)\end{array}$ & $\begin{array}{l}142.71 \\
(56.96)\end{array}$ \\
\hline $\begin{array}{l}\text { Loan Size > } \\
\$ 87 \mathrm{~m}\end{array}$ & 10547 & 5124 & $\begin{array}{l}234.43 \\
(115.03)\end{array}$ & $\begin{array}{l}84.39 \\
(76.17)\end{array}$ & $\begin{array}{l}231.95 \\
(59.78)\end{array}$ & $\begin{array}{l}136.59 \\
(84.40)\end{array}$ & $\begin{array}{l}231.99 \\
(59.91)\end{array}$ & $\begin{array}{l}147.28 \\
(87.03)\end{array}$ & $\begin{array}{l}157.81 \\
(62.01)\end{array}$ & $\begin{array}{l}81.49 \\
(42.30)\end{array}$ & $\begin{array}{l}152.12 \\
(67.06)\end{array}$ & $\begin{array}{l}81.48 \\
(42.65)\end{array}$ \\
\hline $\begin{array}{l}\text { Loan Size < } \\
=\$ 87 \mathrm{~m}\end{array}$ & 14135 & 1544 & $\begin{array}{l}287.64 \\
(133.6)\end{array}$ & $\begin{array}{l}153.70 \\
(104.1)\end{array}$ & $\begin{array}{l}284.20 \\
(56.02)\end{array}$ & $\begin{array}{l}158.01 \\
(49.82)\end{array}$ & $\begin{array}{l}284.19 \\
(56.25)\end{array}$ & $\begin{array}{l}160.32 \\
(49.89)\end{array}$ & $\begin{array}{l}246.10 \\
(58.38)\end{array}$ & $\begin{array}{l}133.49 \\
(47.19)\end{array}$ & $\begin{array}{l}241.32 \\
(63.52)\end{array}$ & $\begin{array}{l}133.51 \\
(47.32)\end{array}$ \\
\hline $\begin{array}{l}\text { Loans with } \\
\text { credit } \\
\text { rating >=B } \\
\text { BB }\end{array}$ & 1,259 & 2,793 & $\begin{array}{l}175.79 \\
(108.0)\end{array}$ & $\begin{array}{l}63.55 \\
(48.85)\end{array}$ & $\begin{array}{l}169.99 \\
(67.26)\end{array}$ & $\begin{array}{l}74.16 \\
(27.06)\end{array}$ & $\begin{array}{l}167.42 \\
(66.41)\end{array}$ & $\begin{array}{l}76.43 \\
(26.98)\end{array}$ & $\begin{array}{l}105.51 \\
(63.61)\end{array}$ & $\begin{array}{l}62.90 \\
(25.14)\end{array}$ & $\begin{array}{l}106.37 \\
(63.57)\end{array}$ & $\begin{array}{l}62.84 \\
(25.11)\end{array}$ \\
\hline $\begin{array}{l}\text { Loans with } \\
\text { credit rating } \\
<\mathrm{BBB}\end{array}$ & 8,766 & 1,184 & $\begin{array}{l}269.75 \\
(122.4)\end{array}$ & $\begin{array}{l}127.59 \\
(106.0)\end{array}$ & $\begin{array}{l}264.59 \\
(60.08)\end{array}$ & $\begin{array}{l}174.69 \\
(69.52)\end{array}$ & $\begin{array}{l}264.53 \\
(60.16)\end{array}$ & $\begin{array}{l}177.62 \\
(70.33)\end{array}$ & $\begin{array}{l}199.83 \\
(72.79)\end{array}$ & $\begin{array}{l}123.22 \\
(77.79)\end{array}$ & $\begin{array}{l}193.87 \\
(78.19)\end{array}$ & $\begin{array}{l}123.24 \\
(77.83)\end{array}$ \\
\hline
\end{tabular}

Note: The estimates are based on the regressions of table 6 . The loan yield spread is measured by the spread over LIBOR which considers the fees paid by the borrower to the lenders expressed in basis points. OLS estimates are fitted from equation 3 and 4. SBA (Selectivity-Bias-Corrected) estimates are fitted from equations 5 adding the inverse Mills ratio as an independent variable. Standard deviations are in parenthesis. The differences in means between the secured and unsecured loan spreads are statistically significant at the 1 percent level.

${ }^{a}$ The average fitted value of the loan yield spread for the secured loans, using coefficient estimates from the OLS SECURED regression.

${ }^{\mathrm{b}}$ The average fitted values of the loan yield spread for the secured loans, using coefficient estimates from the OLS UNSECURED regression.

${ }^{c}$ The average fitted values of the loan yield spread for the secured loans, using coefficient estimates from the SBC SECURED regression.

${ }^{\mathrm{d}}$ The average fitted values of the loan yield spread for the secured loans, using coefficient estimates from the SBC UNSECURED regression. 
${ }^{\mathrm{e}}$ The average fitted values of the loan yield spread for the unsecured loans, using coefficient estimates from the OLS SECURED regression.

${ }^{\mathrm{f}}$ The average fitted values of the loan yield spread for the unsecured loans, using coefficient estimates from the OLS UNSECURED regression.

${ }^{\mathrm{g}}$ The average fitted values of the loan yield spread for the unsecured loans, using coefficient estimates from the SBC SECURED regression.

${ }^{h}$ The average fitted values of the loan yield spread for the unsecured loans, using coefficient estimates from the SBC spread UNSECURED regression.

\section{Conclusion}

We conduct an empirical analysis of the determinants of the use of collateral in syndicated loans and examine debt contract theories under adverse selection and moral hazard. We use syndicated loan data (1978-200) granted to companies located in the United States.

We use a Probit model (Agresti, 2007) to test the magnitude of the effect of the determinants of collateral in syndicated loans. Our results suggest that loan-specific, borrower-specific, and general economic factors are significant in explaining the presence of collateral in syndicated loans. The results also suggest a positive relationship between the use of collateral and the riskiness of the borrower. These factors have also an effect on the loan yield spread.

We then explore the relationship between the yield spread on syndicated loans and the presence of collateral, while using an econometric procedure (Heckman, 1976; Lee, 1987) to correct the interdependence of the decision to use collateral and that to fix the yield spread. Our results show that borrowers are better off borrowing on unsecured basis than on secured basis, confirming the predictions of the moral hazard debt contract theory. Thus, we have clarified further the ambiguities found in the literature regarding the effects of these variables on the likelihood of the use of collateral and on loan yield spreads. Further exploration of the type of collateral (intangible versus tangible assets) may strengthen the link between the pledging of collateral and the pricing of syndicated loans.

An interesting future work would be to conduct a similar analysis of syndicated loans for foreign firms

\section{Acknowledgements}

The authors would like to thank Lin Guo, Georges Tsafack, and seminar participants at Suffolk University and University of Massachusetts at Boston for their comments and suggestions. Any remaining errors are theirs.

\section{References}

Aghion, P., \& Bolton P. (1992). An incomplete contract approach to financial contracting. Review of Economic Studies, 59, 473-494. https://doi.org/10.2307/2297860

Agresti, Alan. (2007). An introduction to categorical data analysis, 423. Wiley-Interscience. https://doi.org/10.1002/0470114754

Avery, R., Bostic, R., \& Samolyk K. (1998). The role of personal wealth in small business finance. Journal of Banking and Finance, 22, 1019-1061. https://doi.org/10.1016/S0378-4266(98)00016-8

Berger, A., \& Udell, G. (1990). Collateral, loan quality, and bank risk. Journal of Monetary Economics, $25,21-24$. https://doi.org/10.1016/0304-3932(90)90042-3

Besanko, D., \& Thakor, A.V. (1987a). Collateral and rationing: Sorting equilibria in monopolistic and competitive credit markets. International Economic Review, 28, 671-689. https://doi.org/10.2307/2526573

Besanko, D., \& Thakor. (1987b). Competitive equilibria in the credit market under asymmetric information. Journal of Economic Theory, 42, 167-182. https://doi.org/10.1016/0022-0531(87)90108-6

Bester, H. (1985). Screening vs. rationing in credit markets with imperfect information. American Economic Review, 75, 850-855.

Boot, A., Thakor, A., \& Udell, G. (1991). Secured lending and default risk: Equilibrium analysis, policy implications and empirical results. Economic Journal, 101, 458-472. https://doi.org/10.2307/2233552

Boot, A., \& Thakor, A. (1994). Moral hazard and secured lending in an infinitely repeated credit market game. International Economic Review, 35, 899-920. https://doi.org/10.2307/2527003 
Booth, J. (1992). Contract costs, bank loans, and the cross-monitoring hypothesis. Journal of Financial Economics, 31, 21-35. https://doi.org/10.1016/0304-405X(92)90010-U

Booth, J., \& Booth, L. (2006). Loan collateral decisions and corporate borrowing costs. Journal of Money, Credit and Banking, 38, 67-90. https://doi.org/10.1353/mcb.2006.0011

Chan, Y., \& Kanatas, G. (1985). Asymmetric valuation and the role of collateral in loan agreements. Journal of Money, Credit and Banking, 17, 85-95. https://doi.org/10.2307/1992508

Chan, Y., S. Greenbaum, \& Thakor, A. (1986). Information reusability, competition and bank asset quality. Journal of Banking and Finance, 10, 255-276. https://doi.org/10.1016/0378-4266(86)90008-7

Davydenko S., \& Franks, J. (2005). Do bankruptcy codes matter? A study of default in France, Germany and the UK. European Finance Association, Moscow Meetings Working Paper. https://doi.org/10.2139/ssrn.647861

Degryse, H., \& Van Cayseele, P. (2000). Relationship lending within a bank-based system: Evidence from European small business data. Journal of Financial Intermediation, 9, 90-109. https://doi.org/10.1006/jfin.1999.0278

Dennis, S., \& Mullineaux, D. (2000). Syndicated loans. Journal of Financial Intermediation, 9, 404-426. https://doi.org/10.1006/jfin.2000.0298

Dennis, S., \& Sharpe, I. (2000). The determinants of contract terms in bank revolving credit agreement. Journal of Financial and Quantitative Analysis, 35, 87-110. https://doi.org/10.2307/2676240

Diamond, D. (1991). Monitoring and reputation: The choice between bank loans and privately placed debt. Journal of Political Economy, 99, 689-721. https://doi.org/10.1086/261775

Diamond, D., \& Verrecchia, R. (1991). Disclosure, liquidity, and the cost of capital. Journal of Finance, 46, 1325-1359. https://doi.org/10.1111/j.1540-6261.1991.tb04620.x

Ederington, L., Yawitz J., \& Roberts, B. (1987). The informational content of bond ratings. Journal of Financial Research, 10, 211-226. https://doi.org/10.1111/j.1475-6803.1987.tb00492.x

Elsas, R., \& Krahnen, J. (1998). Is relationship lending special? Evidence from credit-file data in Germany. Journal of Banking and Finance, 22, 1283-1316. https://doi.org/10.1016/S0378-4266(98)00063-6

Esty, B., \& Megginson, W. (2003). Creditor rights, enforcement, and debt ownership structure: Evidence from the global syndicated loan market. Journal of Financial and Quantitative Analysis, 38, 37-59. https://doi.org/10.2307/4126763

Flannery M. (1986). Asymmetric information and risky debt maturity choice. Journal of Finance, 41, 18-38. https://doi.org/10.1111/j.1540-6261.1986.tb04489.x

Greenbaum, S., Kanatas, G., \& Venezia, I. (1989). Equilibrium loan pricing under the bank-client relationship. Journal of Banking and Finance, 13, 221-235. https://doi.org/10.1016/0378-4266(89)90061-7

Gonas J., Highfield, M., \& Mullineaux, D. (2004). When are commercial loans secured? Financial Review, 39, 79-99. https://doi.org/10.1111/j.0732-8516.2004.00068.x

Gottesman, A. and Roberts, J. (2004). Maturity and corporate loan pricing. Financial Review, 38, 55-77. https://doi.org/10.1111/j.0732-8516.2004.00067.x

Harhoff, D., \& Körting, R. (1998). Lending relationships in Germany: Empirical evidence from survey data. Journal of Banking and Finance, 22, 1317-1353. https://doi.org/10.1016/S0378-4266(98)00061-2

Harris L. (1994). Minimum price variations, discrete bid-ask spreads, and quotation sizes. Review of Financial Studies, 7, 149-178. https://doi.org/10.1093/rfs/7.1.149

Heckman, J. (1976). The common structure of statistical models of truncation, sample selection and limited dependent variables and a simple estimator for such models. Annals of Economic and Social Measurement, 5, 475-492.

Ho, T., \& Saunders, A. (1983). Fixed-rate loan commitments, takedown risk, and the dynamics of hedging with futures. Journal of Financial and Quantitative Analysis, 18, 499-516. https://doi.org/10.2307/2330944

Jackson T., \& Kronman, A. (1979). Secured financing and priorities among creditors. Yale Law Journal, 88, 1143-1182. https://doi.org/10.2307/795626

Jensen, M., \& W. Meckling. (1976). Theory of the firm: managerial behaviour, agency costs and capital structure. Journal of Financial Economics, 3, 305-360. https://doi.org/10.1016/0304-405X(76)90026-X 
Jiménez, G., \& Saurina, J. (2004). Collateral, type of lender and relationship banking as determinants of credit risk. Journal of Banking and Finance, 28, 2119-2212. https://doi.org/10.1016/j.jbankfin.2003.09.002

Jiménez, G., Salas, V., \& Saurina, J. (2006). Determinants of collateral, Journal of Financial Economics, 81, 255-281. https://doi.org/10.1016/j.jfineco.2005.06.003

Jewell J., \& Livingston, M. (1998). Split Ratings, Bond Yields, and Underwriters Spreads, Journal of Financial Research, 21, 185-204. https://doi.org/10.1111/j.1475-6803.1998.tb00679.x

Lee, L. (1978). Unionism and wage rates: A simultaneous equation model with qualitative and limited dependent variables. International Economic Review, 19, 415-433. https://doi.org/10.2307/2526310

Lee, S., \& Mullineaux, D. (2004). Monitoring, financial distress, and the structure of commercial lending syndicates. Financial Management, 33, 107-130.

Leeth, J., \& Scott, J. (1989). The incidence of secured debt: Evidence from the small business community. Journal of Financial and Quantitative Analysis, 24, 379-394. https://doi.org/10.2307/2330818

Kale J., \& Noe, T. (1990). Risky debt maturity choice in a sequential game equilibrium. Journal of Financial Research, 13, 155-166. https://doi.org/10.1111/j.1475-6803.1990.tb00545.x

Mann, R. (1997). Explaining the pattern of secured credit. Harvard Law Review, 628-629. https://doi.org/10.2307/1342242

Manove, M., \& Padilla, A. (2001). Collateral versus project screening: A model of lazy banks. RAND Journal of Economics, 32, 726-744. https://doi.org/10.2307/2696390

Mansi, S., W. Maxwell, \& Miller, D. (2006). Information risk and the cost of debt capital. Working Paper, University of Arizona.

Miller S. (2006). A syndicated loan primer. Standard \& Poor's Guide to the Loan Market.

Moon, C., \& Stotsky, J. (1993). Testing the differences between the determinants of Moody's and Standard and Poor's ratings. Journal of Applied Econometrics, 8, 51-69. https://doi.org/10.1002/jae.3950080105

Myers, S. (1977). Determinants of corporate borrowing. Journal of Financial Economics, 5, 147-176. https://doi.org/10.1016/0304-405X(77)90015-0

Ozler, S. (1992). The evolution of credit terms: An empirical study of commercial bank lending to developing countries. Journal of Development Economics, 38, 79-97. https://doi.org/10.1016/0304-3878(92)90019-6

Petersen, M., \& Rajan, R. (1994). The benefits of lending relationships: Evidence from small business data. Journal of Finance, 49, 3-37. https://doi.org/10.1111/j.1540-6261.1994.tb04418.x

Petersen, M., \& Rajan, R. (1995). The effect of credit market competition on lending relationships. Quarterly Journal of Economics, 110, 406-443. https://doi.org/10.2307/2118445

Rajan, R., \& Winton, A. (1995). Covenants and collateral as incentives to monitor. Journal of Finance, 50, 1113-1146. https://doi.org/10.1111/j.1540-6261.1995.tb04052.x

Sharpe, S. (1990). Asymmetric information, bank lending, and implicit contracts: A stylised model of customer relationships. Journal of Finance, 45, 1069-1087.

Smith, C., \& Warner, J. (1979). On financial contracting: An analysis of bond covenants. Journal of Financial Economics, 7, 117-161. https://doi.org/10.1016/0304-405X(79)90011-4

Stulz, R., \& Johnson H. (1985). An analysis of secured debt. Journal of Financial Economics, 14, 501-22. https://doi.org/10.1016/0304-405X(85)90024-8

Sufi, A. (2007). Information asymmetry and financing arrangements: Evidence from syndicated loans. Journal of Finance, 62, 629-668. https://doi.org/10.1111/j.1540-6261.2007.01219.x

Voordeckers, W., \& Steijvers, T. (2006). Business collateral and personal commitments in SME lending, Journal of Banking and Finance, 30, 3067-3086. https://doi.org/10.1016/j.jbankfin.2006.05.003

White, H. (1980). A heteroscedasticity-consistent covariance matrix estimator and a direct test for heteroscedasticity. Econometrica, 48, 817-838. https://doi.org/10.2307/1912934 


\section{Appendix. Credit rating numerical conversion}

\begin{tabular}{lccc}
\hline $\begin{array}{c}\text { Conversion } \\
\text { Number }\end{array}$ & & $\begin{array}{c}\text { Moody's } \\
\text { Rating }\end{array}$ & S\&P \\
& 22 & Raating & AAA \\
21 & Aa1 & AA+ \\
20 & Aa2 & AA \\
19 & Aa3 & AA- \\
18 & A1 & A+ \\
17 & A2 & A \\
16 & A3 & A- \\
15 & Baa1 & BBB+ \\
13 & Baa2 & BBB \\
12 & Baa3 & BBB- \\
11 & Ba1 & BB+ \\
10 & Ba2 & BB \\
9 & Ba3 & BB- \\
7 & B1 & B+ \\
6 & B2 & B \\
5 & B3 & B- \\
4 & Caa1 & CCC+ \\
3 & Caa2 & CCC \\
2 & Caa3 & CCC- \\
1 & Ca & CC \\
& 14 & C & C \\
& D & D \\
\hline
\end{tabular}

Note: This provides bond-rating conversion codes for Moody's and S\&P ratings used in the analysis.

\section{Notes}

Note 1. In the United States, over 53\% of business loans (Berger \& Udell, 1995) and over $80 \%$ of syndicated loans (Gottesman \& Roberts, 2004) are collateralised. For Germany and France, 76\% and 89\% of these loans are collateralised, respectively (Davydenko \& Franks, 2005).

Note 2. Empirical evidence on the use of collateral in loans contracts is mixed. Berger and Udell (1990), Jimenez and Saurin (2003), and Booth and Booth (2006) find that the use of collateral is associated with riskier loans and riskier borrowers. Degryse and Van Cayseele (2000), and Booth and Booth (2006) find that the use of collateral in loan contracts is associated with lower cost of debt. Berger and Udell (1995), and Harhoff and Korting (1998) find a negative relationship between the intensity of bank-firm relationships and the use of collateral. Jiménez, Salas and Saurina (2006) consider determinants of the use of collateral in loan contracts in the Spanish credit market. They find that the use of collateral is determined in a different way in each segment of the credit market.

Note 3. In 2006, the volume of syndicated loans soared $21 \%$, the largest since 1998 , to $\$ 2.3$ trillion, driven heavily by merger and acquisition type lending (Board of Governors of the FRB System, FDIC, OCC, OTS, 25 September 2007).

Note 4. There is a large literature on the use of collateral in debt contracts (Harhoff and Korting,1998; Berger and Udell, 1990; Berger and Udell, 1995; Degryse and Van Cayseele, 2000; Jimenez and Saurin, 2003; Booth and Booth, 2006a; borrowers., and Booth and Booth, 2006b; Jiménez, Salas and Saurina, 2006).

Note 5. We also use other measures of economic activities and find the same results. Also, during tighter monetary policy or higher real interest rates the likelihood of the use of collateral is small.

Note 6. We find similar results when we use the lagged credit rating as an explanatory variable.

Note 7. For robustness, we re-run the probit model (1) for different subsamples based on different maturities, different sizes and credit ratings and find similar results. 